\title{
Chemical Constituents of the Underground Stem Bark of Duguetia furfuracea (Annonaceae)
}

\author{
Denise B. da Silva, ${ }^{a}$ Elaine C. O. Tulli, ${ }^{a}$ Walmir S. Garcez, ${ }^{b}$ Evandro A. Nascimento ${ }^{c}$ \\ and João M. de Siqueira ${ }^{*, a}$ \\ ${ }^{a}$ Departamento de Farmácia and ${ }^{b}$ Departamento de Química, Universidade Federal do Mato Grosso do Sul, \\ CP 579, 79070-900 Campo Grande-MS, Brazil \\ ${ }^{c}$ Instituto de Química, Universidade Federal de Uberlândia, Av. João Naves de Ávila, 121, \\ Campus Santa Mônica, CP 593, 38400-089 Uberlândia-MG, Brazil
}

\begin{abstract}
No presente trabalho foi realizado um estudo fitoquímico com os diferentes extratos obtidos a partir de órgãos subterrâneos de Duguetia furfuracea (Annonaceae), o qual incluiu o teste de toxicidade para Artemia salina. O extrato alcaloídico, obtido das cascas do caule subterrâneo, conduziu ao isolamento de (-)-duguetina $\beta$ - $N$-óxido, de (-)-duguetina, dicentrinona, (-)- $N$ metiltetraidropalmatina e (+)- $N$-metilglaucina. Do extrato etanólico do cerne do caule subterrâneo obteve-se alantoína por precipitação. O óleo volátil e o extrato apolar também foram extraídos das cascas do caule subterrâneo. As substâncias 2,4,5-trimetoxiestireno, $\alpha$-gurjuneno, aromadendreno, biciclogermacreno, $(E)$-metil-isoeugenol e $\alpha$-asarona foram isoladas a partir do óleo volátil, e as substâncias policarpol, óxido de $\beta$-cariofileno, 2,4,5-trimetóxi-estireno, $\alpha$-asarona e asaraldeído foram obtidas do extrato em éter de petróleo. Este estudo descreve pela primeira vez o alcalóide $\beta$ - $N$-óxido de (-)-duguetina, e a ocorrência das substâncias (-)- $N$ metiltetraidropalmatina e (+)- $N$-metilglaucina na família Annonaceae. Todos os extratos se mostraram tóxicos nos testes com Artemia salina.
\end{abstract}

In the present investigation the underground parts of Duguetia furfuracea (Annonaceae) were used to conduct a phytochemical study that included the brine shrimp (Artemia salina) lethality bioassay. The substances (-)-duguetine $\beta$ - $N$-oxide, (-)-duguetine, dicentrinone, (-)- $N$ methyltetrahydropalmatine, and $(+)-N$-methylglaucine were isolated from the alkaloid extract of the bark of the underground stem, and the ureide allantoin was also isolated by precipitation from the ethanol extract of the wood of the underground stem. A fresh volatile oil and a nonpolar extract were also obtained from the underground stem bark. The substances 2,4,5trimethoxystyrene, $\alpha$-gurjunene, aromadendrene, bicyclogermacrene, $(E)$-methylisoeugenol, and $\alpha$-asarone were isolated from the fresh volatile oil and polycarpol, $\beta$-caryophyllene oxide, $2,4,5$ trimethoxystyrene, $\alpha$-asarone, and asaraldehyde were obtained from the petroleum ether extract. The present study describes for the first time the alkaloid (-)-duguetine $\beta$ - $N$-oxide and the occurrence of (-)- $N$-methyltetrahydropalmatine and (+)-N-methylglaucine in the family Annonaceae. All extracts were active in the brine shrimp lethality bioassay.

Keywords: alkaloids, Annonaceae, aporphines, duguetine $\beta$ - $N$-oxide, Duguetia furfuracea, sesquiterpenoids

\section{Introduction}

Nearly 80 species are known in the genus Duguetia, which is one of the 128 genera included in the family Annonaceae. ${ }^{1}$

This paper reports the results of our continued phytochemical investigations of the family Annonaceae. We analyzed various extracts obtained from the

*e-mail: jmaximo@nin.ufms.br underground stem bark of Duguetia furfuracea (A. St.Hil.) Benth. \& Hook f., which is a shrub distributed throughout the Brazilian state of Mato Grosso do Sul. Two species of the genus Duguetia have been found and worked up to date, and little data on their use in folk medicine can be found in the literature.

D. furfuracea is known as "araticum-seco". ${ }^{2}$ In folk medicine, the seed powder is mixed with water for use in the treatment of pediculosis, ${ }^{3}$ while an infusion of the leaves and twigs is used to treat rheumatism, and a 
medicine derived from this plant is claimed to be useful in the treatment of renal colic. ${ }^{4}$ On the other hand, this species is a major invader of pastures and therefore is harmful to the regional economy, which is based predominantly on agribusiness. Thus, the chemical knowledge of the species could contribute to control its weedy behaviour.

The chemical constituents of the aerial parts (leaves and twigs) of $D$. furfuracea are described in three previous papers. ${ }^{5-7}$ The first paper describes the isolation of sesquiterpenoids; ${ }^{5}$ the other two papers report the isolation of a flavonoid and various alkaloids from an isoquinolinederived skeleton, ${ }^{6}$ and the trypanocidal activity of some of these compounds. One of these papers ${ }^{7}$ describes two aporphine alkaloids containing $N$-nitroso functionality.

The present investigation, which adds to the knowledge of this species, led to the isolation of alkaloids, sesquiterpenoids and other constituents from different extracts obtained from the underground stem bark of $D$. furfuracea.

An alkaloid extract was obtained from the dried and finely ground stem bark, from which (-)-duguetine $\beta$ - $N$-oxide (1), (-)-duguetine (2), dicentrinone (3), (-)- $N$-methyltetrahydropalmatine (4), and (+)- $N$-methylglaucine (5) were isolated. Also, the ureide allantoin (6) was isolated from the ethanol extract of the underground stem (Figure 1).

The substances 2,4,5-trimethoxystyrene (7), $\alpha$-gurjunene (8), aromadendrene (9), bicyclogermacrene (10), (E)-methylisoeugenol (11), and $\alpha$-asarone (12) were isolated from the fresh volatile oil. The substances polycarpol (13), $\beta$-caryophyllene oxide (14), asaraldehyde (15), 7 and 12 were obtained from the petroleum ether extract (Figure 1).

The ${ }^{1} \mathrm{H}$ and ${ }^{13} \mathrm{C}$ NMR data of 1 , including 2D NMR data (NOESY, HMQC and HMBC) and (+) HR-ESIMS characterized this compound as an aporphine alkaloid. To the best of our knowledge, this compound has not been previously reported in the literature. For the first time, substances $\mathbf{6}$ and $\mathbf{1 2}$ are described in the genus Duguetia and substances $\mathbf{4}$ and $\mathbf{5}$, in the family Annonaceae.

\section{Results and Discussion}

The alkaloid extract was fractionated by column chromatography (CC), yielding a novel alkaloid identified as (-)-duguetine $\beta$ - $N$-oxide (1), and four other known alkaloids $(\mathbf{2}, \mathbf{3}, \mathbf{4}, \mathbf{5})$.

Compound 1 was obtained as a brown amorphous solid and exhibited $[\alpha]_{\mathrm{D}}{ }^{20}-33.3(\mathrm{MeOH}, c 0.001)$. Its molecular formula $\left(\mathrm{C}_{20} \mathrm{H}_{21} \mathrm{NO}_{6}\right)$ was determined using HR-ESIMS $\left(m / z\right.$ 372.1413, $\left.[\mathrm{M}+\mathrm{H}]^{+}\right)$. Its FTIR spectrum revealed the presence of a hydroxyl group $\left(3418 \mathrm{~cm}^{-1}\right)$ and an aliphatic system (2959-2846 $\left.\mathrm{cm}^{-1}\right)$. The ${ }^{1} \mathrm{H}$ NMR data showed three hydrogen signals in the aromatic region at $\delta 7.53(\mathrm{~s}), 7.30(\mathrm{~s})$, and $6.47(\mathrm{~s})$ and an $\mathrm{N}$ linked methyl group at $\delta 3.24(\mathrm{~s})$.

The presence of 1,2-methylenedioxy and 9,10dimethoxy groups was indicated in the NMR spectrum

Table 1. NMR spectroscopic data of compound 1

\begin{tabular}{|c|c|c|c|c|c|}
\hline \multirow[b]{2}{*}{$\mathrm{C}$} & \multirow[b]{2}{*}{$\delta_{\mathrm{C}}$} & \multirow[b]{2}{*}{$\delta_{\mathrm{H}}$} & \multicolumn{2}{|c|}{ HMBC } & \multirow[t]{2}{*}{ NOESY } \\
\hline & & & ${ }^{2} J_{\mathrm{CH}}$ & ${ }^{3} J_{\mathrm{CH}}$ & \\
\hline 1 & 142.7 & - & $\mathrm{H}-3$ & $\mathrm{O}-\mathrm{CH} 2-\mathrm{O}$ & \\
\hline $1 \mathrm{a}$ & 115.9 & - & & H-11 & \\
\hline $1 b$ & 118.8 & - & H-6a & H-3 & \\
\hline 2 & 148.6 & - & $\mathrm{H}-3$ & $\mathrm{O}-\mathrm{CH} 2-\mathrm{O}$ & \\
\hline 3 & 106.3 & $6.47(\mathrm{~s})$ & & & $2.91(\mathrm{H}-4)$ \\
\hline $3 a$ & 122.9 & - & & $\mathrm{H}-5$ & \\
\hline 4 & 27.0 & $2.91(\mathrm{~m})$ & & H-3 & $3.59(\mathrm{H}-5)$ \\
\hline 5 & 66.8 & $3.59(\mathrm{~m})$ & & $\mathrm{N}-\mathrm{CH}_{3}$ & \\
\hline $6 a$ & 76.4 & $4.34(\mathrm{~d}, 12.1)$ & $\mathrm{H}-7$ & $\mathrm{~N}-\mathrm{CH}_{3}$ & $3.59(\mathrm{H}-5)$ \\
\hline 7 & 68.3 & $5.08(\mathrm{~d}, 12.1)$ & H-6a & H-8 & \\
\hline $7 \mathrm{a}$ & 130.4 & - & $\mathrm{H}-8, \mathrm{H}-7$ & H-11 & \\
\hline 8 & 107.3 & $7.30(\mathrm{~s})$ & & & $3.90\left(\mathrm{OCH}_{3}\right)$ \\
\hline 9 & 147.9 & - & $\mathrm{H}-8$ & $\mathrm{H}-11, \mathrm{OCH}_{3}$ & \\
\hline 10 & 149.3 & - & H-11 & $\mathrm{H}-8, \mathrm{OCH}_{3}$ & \\
\hline 11 & 109.8 & $7.53(\mathrm{~s})$ & & & $3.84\left(\mathrm{OCH}_{3}\right)$ \\
\hline $11 \mathrm{a}$ & 119.5 & - & H-11 & $\mathrm{H}-8, \mathrm{H}-7$ & \\
\hline $\mathrm{N}-\mathrm{CH}_{3}$ & 48.8 & $3.24(\mathrm{~s})$ & & & $5.08(\mathrm{H}-7)$ \\
\hline $\mathrm{O}-\mathrm{CH}_{2}^{3}-\mathrm{O}$ & 101.3 & $5.93(\mathrm{~d}, 1.1) 6.10(\mathrm{~d}, 1.1)$ & & $\mathrm{H}-3$ & \\
\hline $\mathrm{OCH}_{3}^{2}(9)$ & 55.9 & $3.84(\mathrm{~s})$ & & & \\
\hline $\mathrm{OCH}_{3}(10)$ & 55.8 & $3.90(\mathrm{~s})$ & & & \\
\hline
\end{tabular}

${ }^{1} \mathrm{H}$ and ${ }^{13} \mathrm{C} \mathrm{NMR}$ spectra were acquired in $\mathrm{CDCl}_{3}$ at 300 and $75 \mathrm{MHz}$ respectively. TMS was used as internal standard, chemical shifts are shown in the $\delta$ scale with $J$ values $(\mathrm{Hz})$ in parentheses. 
by two singlet signals at $\delta 3.84(\mathrm{~s})$ and $3.90(\mathrm{~s})$, and the typical pair of doublets of methylenedioxy protons was observed at $\delta 6.10$ and $5.93(\mathrm{~d}, 1.1 \mathrm{~Hz})$. Also, were observed aliphatic protons signals at $\delta 3.59(\mathrm{~m})$ and $2.91(\mathrm{~m})$. These ${ }^{1} \mathrm{H}$ NMR data (Table 1 ) are in agreement with an aporphine alkaloid having 1,2methylenedioxy and 7-hydroxy groups with trans configuration at $6 \mathrm{a}, 7$, exhibiting a large coupling constant for the two doublets at $\delta 5.08(\mathrm{~d}, 12.1 \mathrm{~Hz})$ and 4.34 (d, $12.1 \mathrm{~Hz})$.

The ${ }^{13} \mathrm{C}$ NMR data were also in agreement with the observations (Table 1), but the chemical shift of carbon atoms in the neighborhood of the N-heterocycle suggests the presence of an $\mathrm{N}-\mathrm{O}$ group, as the $\mathrm{N}$-heterocycle region showed a more pronounced deshielding effect than in duguetine (2) (Figure 2).

This effect is in accordance with the molecular formula established by HR-MS, indicating the presence of an additional oxygen atom. ${ }^{8}$ By comparing the ${ }^{13} \mathrm{C}$ NMR data of $\mathbf{1}$ with those of $\mathbf{2}$, using N-O models available in the literature, namely oliveroline $\beta-N$-oxide $(6 \mathrm{a}, 7 \alpha-\mathrm{H}, \beta-N$ oxide $^{9}$ and dasymaschaline $\alpha$ - $N$-oxide $(6 \mathrm{a}, 7 \alpha-\mathrm{H}, \alpha-N$ oxide), ${ }^{8}$ and confirming with NOESY the stereochemistry of the $\mathrm{N}$-oxide moiety of $\mathbf{1}$, it was possible to propose that $\mathbf{1}$ is a (-)-duguetine $\beta$-N-oxide (Table 1).

Allantoin (6) was isolated from the ethanol extract by precipitation with acetone and its spectral data were agree with those in the literature. ${ }^{10}$ This metabolite<smiles>COc1cc2c(cc1OC)[C@H](O)c1c3c(cc([C@H](C)N(C)O)c1-2)OCO3</smiles>

1

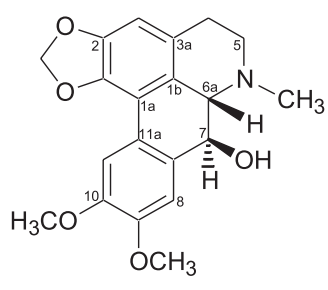

2<smiles></smiles>

3<smiles>COc1cc2c(cc1OC)[C@H]1Cc3ccc(OC)c(OC)c3C[C@H]1N(C)CC2</smiles>

4<smiles>COc1cc2c(cc1OC)-c1c(OC)c(OC)cc3c1[C@@H](C2)N(C)CC3</smiles>

5<smiles>NC(=O)N[C@@H]1NC(=O)NC1=O</smiles>

6<smiles>[R]/C=C/c1cc(OC)c(OC)cc1[R]</smiles>

$\begin{aligned} 7 & \mathrm{R}^{1}=\mathrm{H}, \mathrm{R}^{2}=\mathrm{OCH}_{3} \\ 11 & \mathrm{R}^{1}=\mathrm{CH}_{3}, \mathrm{R}^{2}=\mathrm{H} \\ 12 & \mathrm{R}^{1}=\mathrm{CH}_{3}, \mathrm{R}^{2}=\mathrm{OCH}_{3}\end{aligned}$

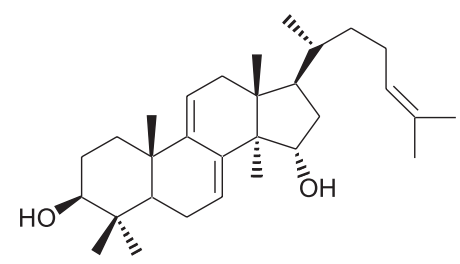

13

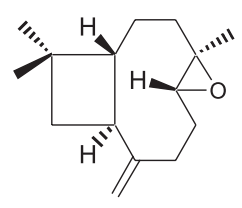

14<smiles>COc1cc(OC)c(OC)cc1C=O</smiles>

Figure 1. Chemical constituents of D. furfuracea. 
belongs to the ureide class and plays an important role in the transport and assimilation in some nitrogen-fixing species. ${ }^{11}$ Allantoin, which is also used in cosmetics, ${ }^{12}$ exhibits anti-inflammatory activity among other properties. This compound has already been obtained in large amounts from the underground parts of other pasture-invading species. ${ }^{10}$

The fresh volatile oil was fractionated by $\mathrm{CC}$ on silica gel, yielding several fractions. The fractions, composed of a mixture of two compounds, were subjected to an additional preparative thin layer chromatography (TLC) followed by preparative argentation TLC separation, and six compounds (7-12) were isolated and identified by comparison of their spectral data with literature values (see Experimental section). In order to contribute to the chemical knowledge of nonpolar compounds from the fresh stem bark, the fresh volatile oil was subjected to GC/MS

Table 2. Chemical constitution of the fresh volatile oil of the underground stem bark of Duguetia furfuracea

\begin{tabular}{|c|c|c|}
\hline Compounds & Rt & $\%$ \\
\hline$\alpha$-gurjunene ${ }^{*}$ & 31.1 & 2.1 \\
\hline trans-caryophyllene & 31.4 & 3.2 \\
\hline aromadendrene ${ }^{*}$ & 31.9 & 2.2 \\
\hline$\alpha$-humulene & 33.4 & 0.8 \\
\hline 7,9(11)-drimadiene & 34.1 & 1.5 \\
\hline$\gamma$-gurjunene & 34.3 & 0.9 \\
\hline bicyclogermacrene* & 35.3 & 8.6 \\
\hline$\gamma$-cadinene & 36.3 & 2.8 \\
\hline 2,4,5-trimethoxystyrene ${ }^{*, * *}$ & 37.7 & 29.2 \\
\hline palustrol & 38.0 & 1.1 \\
\hline spathulenol & 38.8 & 4.7 \\
\hline caryophyllene oxide $^{* *}$ & 39.0 & 2.2 \\
\hline viridiflorol & 39.4 & 1.4 \\
\hline epi-globulol & 39.9 & 6.4 \\
\hline 1-epi-cubenol & 40.7 & 0.7 \\
\hline epi- $\alpha$-cadinol & 41.2 & 2.7 \\
\hline valerianol & 41.7 & 1.0 \\
\hline$\alpha$-asarone ${ }^{*, * *}$ & 42.4 & 23.8 \\
\hline asaraldehyde ${ }^{* *}$ & 43.8 & 1.6 \\
\hline Not identified & 47.3 & 3.1 \\
\hline
\end{tabular}

Some of the compounds in Table 2 were also identified by conventional phytochemical work up of the fresh volatile oil $(*)$ or petroleum ether extract $(* *)$ or both. analysis. The compounds identified by this method are listed in Table 2.

In a further chemical investigation of the fresh stem bark, the petroleum ether extract yielded, by the usual phytochemical work up, 7, 12, 13, 14 and 15 (Figure 1).

Volatile and nonpolar compounds have been described in Annonaceae. ${ }^{13}$ Essential oils, for instance, are responsible for the fragrance of several species and their chemical composition generally includes well-known monoterpenes, sesquiterpenes, or aromatic compounds. ${ }^{14}$

A noteworthy feature is the fact that the isolation of aromatic compounds such as propenylbenzenes (or vinylbenzenes) has been described predominantly in the underground parts. ${ }^{14,15}$ Phenylpropanoid-derived compounds are widespread among vascular plants and play an important role in chemical defense. ${ }^{16}$

With regard to polycarpol (13), it has been described as a chemical marker of the family Annonaceae, however it has recently been found in another plant family. ${ }^{17}$

The fresh volatile oil and the petroleum ether and alkaloid extracts were active in the brine shrimp lethality bioassay, with $\mathrm{LD}_{50}$ values of 2.6, 6.1, and $36.9 \mu \mathrm{g} \mathrm{mL}^{-1}$, respectively.

The toxicity exhibited by the extracts and fresh volatile oil might be explained by the presence of active substances previously tested in the brine shrimp lethality bioassay, namely 2,4,5-trimethoxystyrene (7) $\left(\mathrm{LD}_{50}=8 \mu \mathrm{g} \mathrm{mL}^{-1}\right){ }^{18}$ found in both the fresh volatile oil and petroleum ether extract, polycarpol (13) $\left(\mathrm{LD}_{50}=254 \mu \mathrm{g} \mathrm{mL}{ }^{-1}\right),{ }^{19}$ in the petroleum ether extract, and several oxoaporphine alkaloids. $^{20}$

\section{Experimental}

\section{General experimental procedures}

Optical rotations were measured on a Perkin-Elmer 341 polarimeter in $\mathrm{MeOH}$. The FTIR spectra of either $\mathrm{KBr}$ pellets or $\mathrm{CHCl}_{3}$ films were obtained on a Perkin Elmer 783 spectrophotometer. The MS system (HR-ESIMS) used

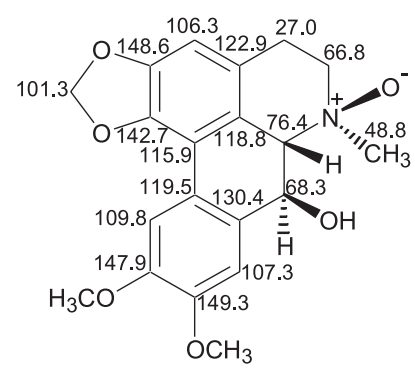

1

Figure 2. Comparison between ${ }^{13} \mathrm{C}\left(75 \mathrm{MHz}, \mathrm{CDCl}_{3}\right)$ spectral data of $\mathbf{1}$ and $\mathbf{2}$. 
was a quadrupole time-of-flight instrument (UltrOTOFQ, Bruker Daltonics, Billerica, MA), equipped with an ESI source; the analyses were performed with the mass spectrometer in the positive ion mode. The GC/MS data were obtained on a CG17A/QP5000 Shimadzu GC/MS instrument equipped with a DB-5 capillary column using $\mathrm{He}$ as the carrier gas. The ${ }^{1} \mathrm{H}$ and ${ }^{13} \mathrm{C} 1 \mathrm{D}$ and $2 \mathrm{D}$ NMR spectra were recorded at $300 \mathrm{MHz}\left({ }^{1} \mathrm{H}\right)$ and $75 \mathrm{MHz}\left({ }^{13} \mathrm{C}\right)$ on a Bruker DPX-300 spectrometer.

\section{Plant material}

The underground parts (stem bark and wood) of Duguetia furfuracea (A. St.-Hil.) Benth. \& Hook f. were collected in March 2004, on the UFMS campus in Campo Grande, MS, Brazil, and identified by Prof. R. Mello-Silva. A voucher specimen (No. 023) was deposited in the CGMS Herbarium (UFMS, Campo Grande, MS).

\section{Extraction and isolation of compounds}

Ammonium hydroxide was added to $1300 \mathrm{~g}$ of airdried and finely ground bark of the underground stem until $\mathrm{pH} 9.0$ was reached and then subjected to exhaustive extraction with $\mathrm{CHCl}_{3}$. The resulting chloroform layer was concentrated under reduced pressure and a brown residue (68 g) was obtained.

The residue was solubilized in $\mathrm{CHCl}_{3}$ and extracted with $5 \% \mathrm{HCl}$; the resulting acid fraction was adjusted to $\mathrm{pH} 9.0$ $\left(\mathrm{NH}_{4} \mathrm{OH}\right)$ and again exhaustively extracted with $\mathrm{CHCl}_{3}$.

A brown precipitate was obtained $(9.2 \mathrm{~g})$. This extract (7.2 g) was fractionated by CC on alumina (70-230 mesh) and eluted with $\mathrm{CHCl}_{3}: \mathrm{MeOH}: \mathrm{H}_{2} \mathrm{O}$ gradient system to yield thirteen fractions (I-XIII).

Fractions IV, X and XI from this column provided 2 (812.1 mg), 4 (69.3 mg) and 5 (11.2 mg). Fraction V (800 $\mathrm{mg}$ ) was fractionated by CC on silica gel (70-230 mesh) in $\mathrm{CHCl}_{3}: \mathrm{MeOH}: \mathrm{H}_{2} \mathrm{O}$. Fractions 60-75 yielded $\mathbf{3}$ (4.6 mg). Fraction VII $(378.9 \mathrm{mg})$ yielded 1 after CC on silica gel (70-230 mesh) eluted with $\mathrm{CHCl}_{3}$ :EtOAc:MeOH: $\mathrm{H}_{2} \mathrm{O}$ gradient system.

From the ethanol extract of the underground stem, the ureide allantoin (6) was isolated by precipitation with acetone.

The alkaloids 2, 3, $\mathbf{4}$ and $\mathbf{5}$, as well as the compounds 6-12 were identified by ${ }^{1} \mathrm{H}$ and ${ }^{13} \mathrm{C}$ NMR spectroscopy and compared with literature values. ${ }^{10,18-31}$

\section{(-)-Duguetine $\beta$-N-oxide, (1)}

Brown amorphous solid; Rf $0.51(\mathrm{CHCl} 3: \mathrm{MeOH}$, 85.15); $[\alpha]_{\mathrm{D}}^{20}:-33.3^{\circ}\left(\mathrm{MeOH} ; c 0.001\right.$,); FTIR (KBr) $v_{\max }{ }^{\prime}$ $\mathrm{cm}^{-1}: 3418,2959,2929,2846,1607,1515,1463,1393$,
1340, 1244, 1226, 1217, 1118, 1046, 993, 945, 870; (+) HR-ESIMS $m / z$ : $372.1413[\mathrm{M}+\mathrm{H}]^{+}$(Calc. for $\mathrm{C}_{20} \mathrm{H}_{22} \mathrm{NO}_{6}$ requires 372.1436). ${ }^{1} \mathrm{H}$ NMR (300 $\mathrm{MHz}, \mathrm{CDCl}_{3}, \delta$ ) and ${ }^{13} \mathrm{C}$ NMR $\left(75 \mathrm{MHz}, \mathrm{CDCl}_{3}, \delta\right)$ : see Table 1.

\section{(-)-N-Methyltetrahydropalmatine, (4)}

Brown amorphous solid; $[\alpha]_{\mathrm{D}}^{20}:-104.1^{\circ}(\mathrm{MeOH} ; c$ 0.0012). FTIR, ${ }^{1} \mathrm{H}$ and ${ }^{13} \mathrm{C}$ NMR data are in agreement with those reported in the literature. ${ }^{30}$

\section{(+)-N-Methylglaucine, (5)}

Brown amorphous solid; $[\alpha]_{\mathrm{D}}^{20}:+34.9^{\circ}(\mathrm{MeOH} ; c$ 0.0012). FTIR, ${ }^{1} \mathrm{H}$ and ${ }^{13} \mathrm{C}$ NMR data are in agreement with those reported in the literature. ${ }^{31} \mathrm{~A}$ 4-hour hydrodistillation of $300 \mathrm{~g}$ of fresh bark of underground stem, using a Clevenger-type apparatus, yielded $1.2 \%$ fresh volatile oil.

The oil was fractionated by CC on silica gel (70-230 mesh), and eluted with petroleum ether: $\mathrm{CHCl}_{3}: \mathrm{MeOH}$ gradient system to yield thirteen combined fractions (I$\mathrm{XIII})$. Compound $7(117.1 \mathrm{mg})$ was identified as the major component of fraction XII, and compound 12 (160.2 mg), of fraction XIII. Fractions II and XI from this column provided $8(19.5 \mathrm{mg})$ and $\mathbf{1 1}(10.1 \mathrm{mg})$, respectively. Fractions III and VI were purified by preparative/ argentation TLC yielding $\mathbf{9}(9.1 \mathrm{mg})$ and $\mathbf{1 0}(17.2 \mathrm{mg})$, respectively.

A separate amount of air-dried and finely ground bark of the underground stem (155 g) was subjected to exhaustive petroleum ether extraction in a Soxhlet apparatus; the resulting extract was concentrated in vacuo to dryness $(13 \mathrm{~g})$. The precipitate from this extract was purified by recrystallization from hexane and $\mathrm{CHCl}_{3}$ providing 13 (176.4 $\mathrm{mg})$. The resulting extract $(5 \mathrm{~g})$ was then fractionated by CC on silica gel (70-230 mesh) using hexane: $\mathrm{CHCl}_{3}: \mathrm{MeOH}$ as elution gradient. The fractions showing similar spots on TLC were combined into twelve fractions (I-XII). Fractions I and IX provided 14 (11.8 $\mathrm{mg})$ and $\mathbf{1 5}(12.3 \mathrm{mg})$, respectively. Fraction X (235.2 $\mathrm{mg}$ ) yielded a mixture of $\mathbf{7}$ and $\mathbf{1 2}$.

\section{Brine shrimp lethality test}

The brine shrimp (A. salina Leach) toxicity tests were conducted using second instar larvae according to the method of McLaughlin. Stock solutions of samples were prepared by dissolving $15 \mathrm{mg}$ of the test material in $5 \mathrm{~mL}$ of sea water containing $1 \%(\mathrm{v} / \mathrm{v})$ DMSO. The assays were carried out in triplicate on samples at a concentration of 500, 50, 5.0 and $0.5 \mu \mathrm{g} \mathrm{mL}^{-1}$. Positive (Quinidine Sulfate) and negative (sea water containing $0.1 \%(\mathrm{v} / \mathrm{v})$ DMSO) 
controls were included in each bioassay in order to verify the susceptibility of the brine shrimps. $\mathrm{LD}_{50}$ values were determined from $24 \mathrm{~h}$ counts, by Probit Analysis. ${ }^{32}$

\section{Acknowledgments}

The authors acknowledge the financial support provided by FUNDECT - Fundação de Apoio ao Desenvolvimento do Ensino, Ciência e Tecnologia do Estado de Mato Grosso do Sul, Brazil. They are also thankful to CNPq for the fellowship granted. Thanks are also due to Dr. Norberto Peporine Lopes (Faculdade de Ciências Farmacêuticas de Ribeirão Preto/USP, SP, Brazil) for mass spectrometry analysis.

\section{References}

1. Muhammad, I.; Dunbar, D. C.; Takamatsu, S.; Walker, L. A.; Clark, A. M.; J. Nat. Prod. 2001, 64, 559.

2. Lorenzi, H.; Plantas Daninhas do Brasil: Terrestres, Aquáticas, Parasitas e Tóxicas; Plantarum: Nova Odesa, Brazil, 2000, p. 62.

3. Silberbauer-Gottsberger, I.; Abstract of VII Simpósio de Plantas Medicinais do Brasil, Belo Horizonte, Brazil, 1981/2.

4. Rodrigues, V. E. G.; Carvalho, D. A.; Cienc. Agrotec. 2001, 25, 102; Da Silva Coelho, L.; Patent BR 200202030-A, 2004.

5. Carollo, C. A.; Hellman, A. R.; Siqueira, J. M.; Biochem. Syst. Ecol. 2005, 33, 647.

6. Carollo, C. A.; Hellmann-Carollo, A. R.; Siqueira, J. M. de; Albuquerque, S.; J. Chil. Chem. Soc. 2006, 51, 837.

7. Carollo, C. A.; Siqueira, J. M.; Garcez, W. S.; Diniz, R.; Fernandes, N. G.; J. Nat. Prod. 2006, 69, 1222.

8. Asaruddin, M. R.; Kiuchi, F.; Honda, G.; Nat. Med. 2001, 55, 149.

9. Guinaudeau, H.; Leboeuf, M.; Cavé, A.; J. Nat. Prod. 1994, 57, 1033.

10. Ferreira, D. T.; Alvares, P. S.; Houghton, P. J.; Braz-Filho, R. B.; Quim. Nova 2000, 23, 42; Grassi, R. F.; Resende, U. M.; Silva, W.; Macedo, M. L. R.; Butera, A. P.; Tulli, E. O.; Saffran, F. P.; Siqueira, J. M. de; Quim. Nova 2005, 28, 199.

11. Hopkins, W. G.; Introduction to Plant Physiology, Willey: London, 1995, ch. 6.

12. Martindale, W.; The Extra Pharmacopoeia, $30^{\text {th }}$ ed., James, E. F.; Reynolds, eds.; The Pharmaceutical Press: London, 1993; Joanne, M. M.; Cosmetic Ingredient Handbook, $1^{\text {st }}$ ed., Washington: Cosmetic, Toiletry and Fragrance Association, 1988. Reference Stacks TP 983.C953 1988, p. 108.

13. Leboeuf, M.; Cavé, A.; Bhaumik, P. K.; Mukherjee, B.; Mukherjee, R.; Phytochemistry 1982, 21, 2783.
14. Fournier, G.; Leboeuf, M.; Cavé, A.; J. Essent. Oil Res. 1999, 11,131 .

15. Maia, J. G. S.; Andrade, E. H. A.; Carreira, L. M. M.; Oliveira, J.; J. Essent. Oil Res. 2006, 18, 60.

16. Lane, A. L.; Kubanek, J.; Phytochemistry 2006, 67, 1224.

17. Jayasuriya, H.; Herath, K. B.; Ondeyka, J. G.; Guan, Z.; Bpris, R. P.; Tiwari, S.; Jong, W.; Chavez, F.; Moss, J.; Stevenson, D. W.; Beck, H. T.; Slattery, M.; Zamora, N.; Schulman, M.; Ali, A.; Sharma, N.; Macnaul, K.; Hayes, N.; Menke, J. G.; Singh, S. B.; J. Nat. Prod. 2005, 68, 1247.

18. Wang, Z-W.; Ma, W-W.; McLaughlin, J. L.; Gupta, M. P.; J. Nat. Prod. 1988, 51, 382.

19. Jung, J. H.; Pummangura, S.; Chaichantipyuth, C.; Patarapanich, C.; McLaughlin, J. L.; Phytochemistry 1990, 29, 1667.

20. Siqueira, J. M. de; Ziminiani, M. G.; Resende, U. M.; Boaventura, M. A. D.; Quim. Nova 2001, 24, 185; Wu, Y-C.; Chang, G-Y.; Duh, C-Y.; Wang, S-K.; Phytochemistry 1993, 33, 497.

21. Nagashima, F.; Murakami, Y.; Aasakawa, Y.; Phytochemistry 1999, 51, 1101.

22. Krishnappa, S.; Dev, S.; Phytochemistry 1973, 12, 823; Atta-Ur-Rahman; Ahmad, V. U.; ${ }^{13}$ C NMR of Natural Products (Monoterpenes and Sesquiterpenes), vol. 1, Plenum Press: New York, 1992, p. 467.

23. Miyazawa, M.; Uemura, T.; Kameoka, H.; Phytochemistry 1995, 40, 793.

24. Ferreira, M. J. P.; Costantin, M. B.; Sartorelli, P.; Rodrigues, G. V.; Limberger, R.; Henriques, A. T.; Kato, M. J.; Emerenciano, V. P.; Anal. Chim. Acta 2001, 447, 125.

25. Joshi, B. P.; Sharma, A.; Sinha, A. K.; Tetrahedron 2005, 61, 3075.

26. González, M. C.; Sentandreu, M. A.; Rao, K. S.; Zafra-Polo, M. C.; Cortes, D.; Phytochemistry 1996, 43, 1361.

27. Silverstein, R. M.; Webster, F. X.; Identificação Espectrométrica de Compostos Orgânicos, $6^{\text {th }}$ ed., LTC: Rio de Janeiro, Brazil, 2000.

28. Navarro, V. R.; Sette, I. M. F.; Da-Cunha, E. V. L.; Silva, M. S.; Barbosa-Filho, J. M.; Maia, J. G. S.; Rev. Bras. Plant. Med. 2001, 3, 23.

29. Zhou, B.; Johson, R. K.; Mattern, M. R.; Xiangyang, W.; Hecht, S. M.; Beck, H. T.; Ortiz, A.; Kingston, D. G. I.; J. Nat. Prod. 2000, 63, 217.

30. Calderwood, J. M.; Finkelstein, N.; Fish, F.; Parfitt, R. T.; Phytochemistry 1971, 10, 682.

31. Marsaioli, A. J.; Rúveda, E. A.; Reis, F. A. M.; Kuck, A. M.; Magalhães, A. F.; Phytochemistry 1979, 18, 165.

32. Meyer, B. N.; Ferrigni, J. E.; Putnam, J. E.; Jacobsen, L. B.; Nichols, D. E.; McLaughlin, J. L.; Planta Med. 1982, 45, 31; Finney, D. J.; Probit Analysis, $3^{\text {rd }}$ ed., Cambridge University Press: Cambridge, 1971.

Received: December 11, 2006 Web Release Date: December 13, 2007 


\title{
Chemical Constituents of the Underground Stem Bark of Duguetia furfuracea (Annonaceae)
}

\author{
Denise B. da Silva, ${ }^{a}$ Elaine C. O. Tulli, ${ }^{a}$ Walmir S. Garcez, ${ }^{b}$ Evandro A. Nascimento ${ }^{c}$ \\ and João M. de Siqueira ${ }^{*, a}$ \\ ${ }^{a}$ Departamento de Farmácia and ${ }^{b}$ Departamento de Química, Universidade Federal do Mato Grosso do Sul, \\ CP 579, 79070-900 Campo Grande-MS, Brazil \\ ${ }^{c}$ Instituto de Química, Universidade Federal de Uberlândia, Av. João Naves de Ávila, 121, \\ Campus Santa Mônica, CP 593, 38400-089 Uberlândia-MG, Brazil
}

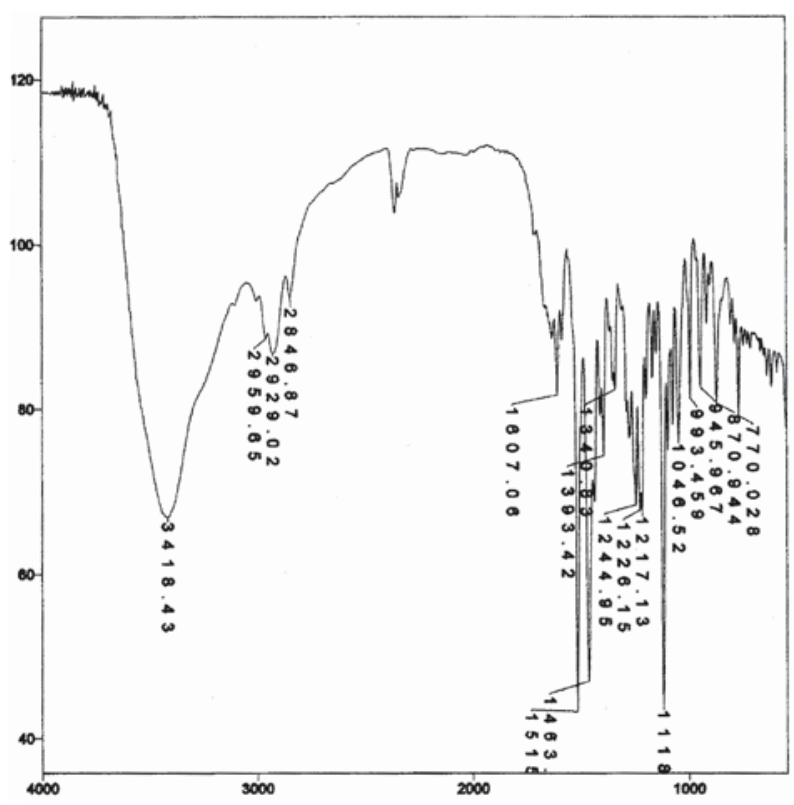

Figure S1. FTIR spectrum of compound 1. 


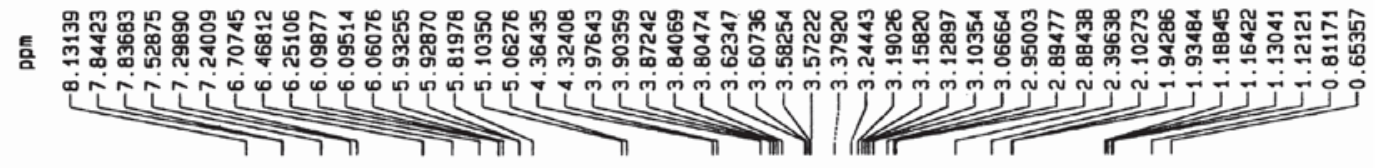<smiles></smiles>
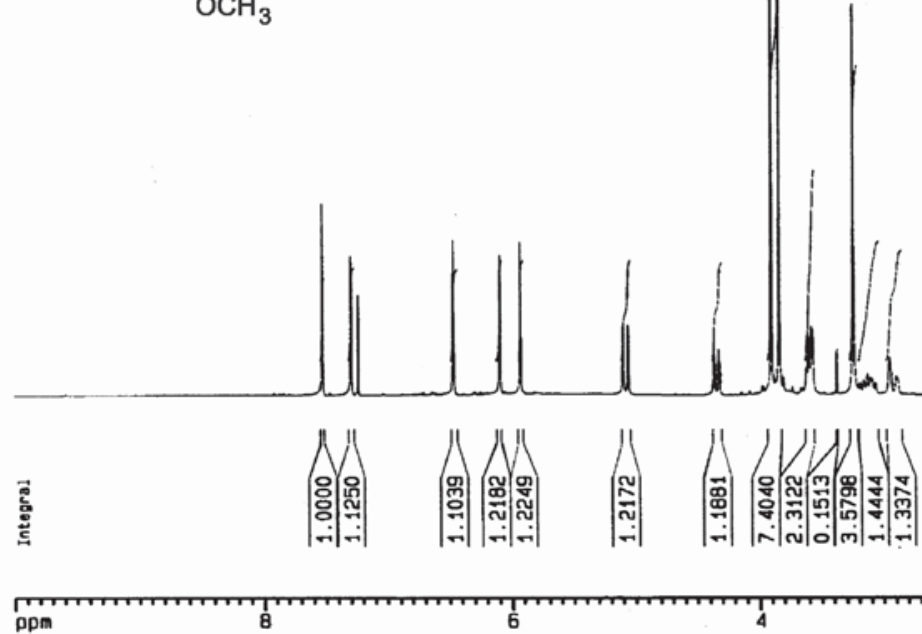

Figure S2. ${ }^{1} \mathrm{H}$ NMR spectrum of compound 1 ( $\left.300 \mathrm{MHz}, \mathrm{CDCl}_{3}\right)$.

言

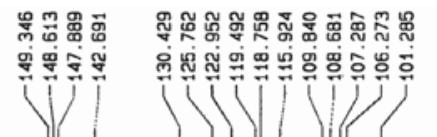

กิ๊

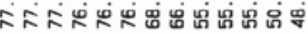

W11 111<smiles>COc1cc2c(cc1OC)[C@H](O)[N+](C)([O-])CCc1cc3c(c(O)c1-2)OCO3</smiles>

${ }_{\mathrm{ipm}}^{\mathrm{mm}}$
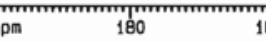

160

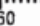

140

${ }_{120}^{120}$

100

80

60

40

20

Figure S3. ${ }^{13} \mathrm{C}$ NMR spectrum of compound $1\left(75 \mathrm{MHz}, \mathrm{CDCl}_{3}\right)$. 


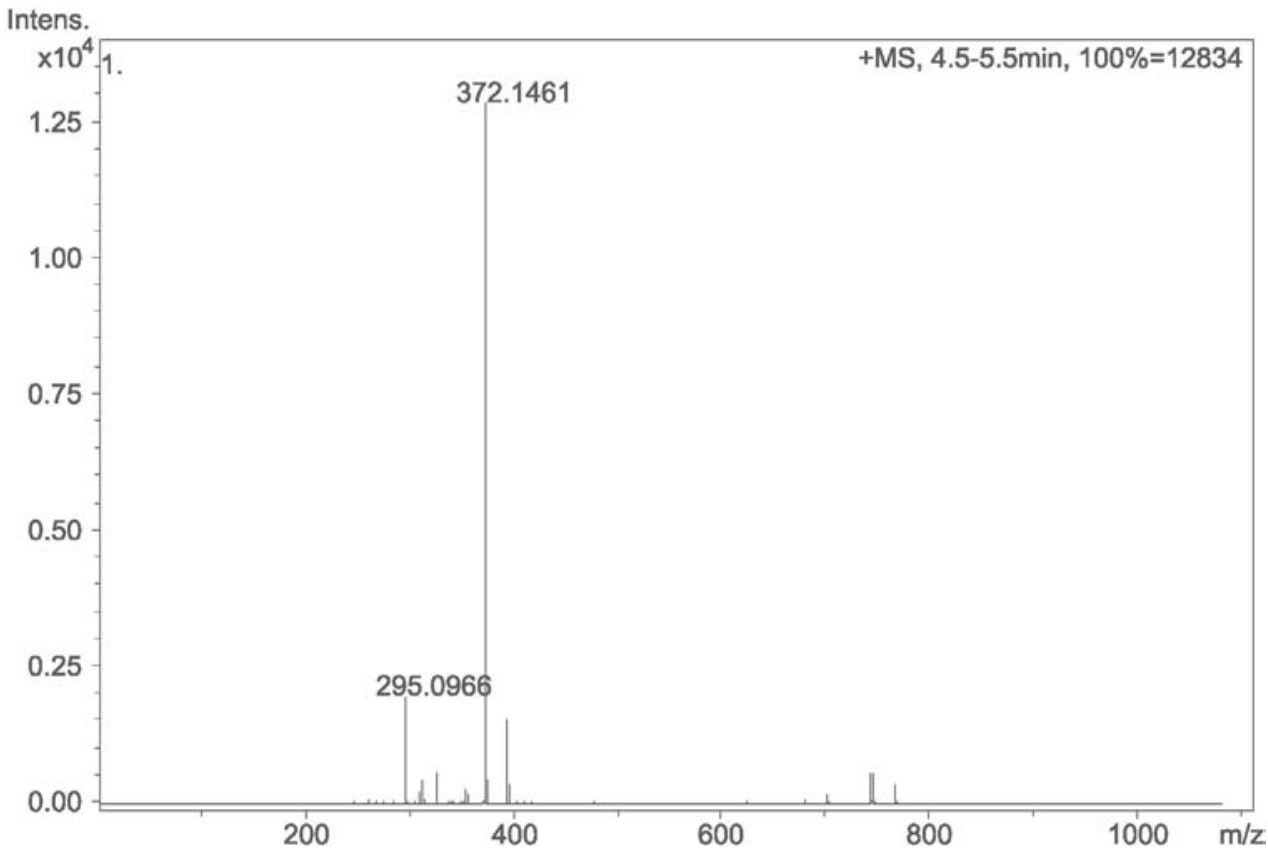

Figure S4. HR-ESIMS spectrum of compound 1 (positive mode).

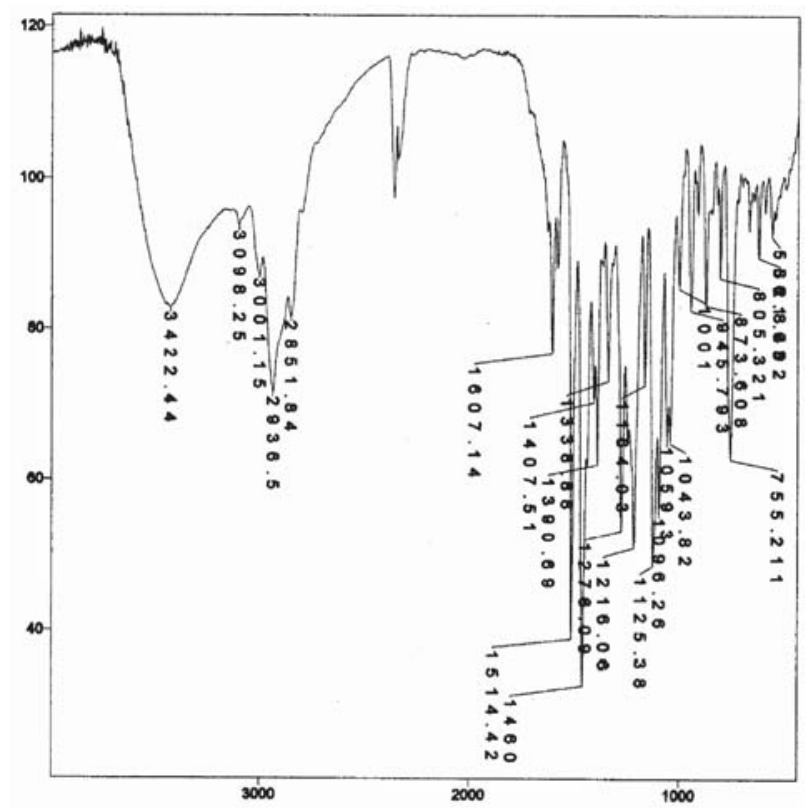

Figure S5. FTIR spectrum of compound 2. 


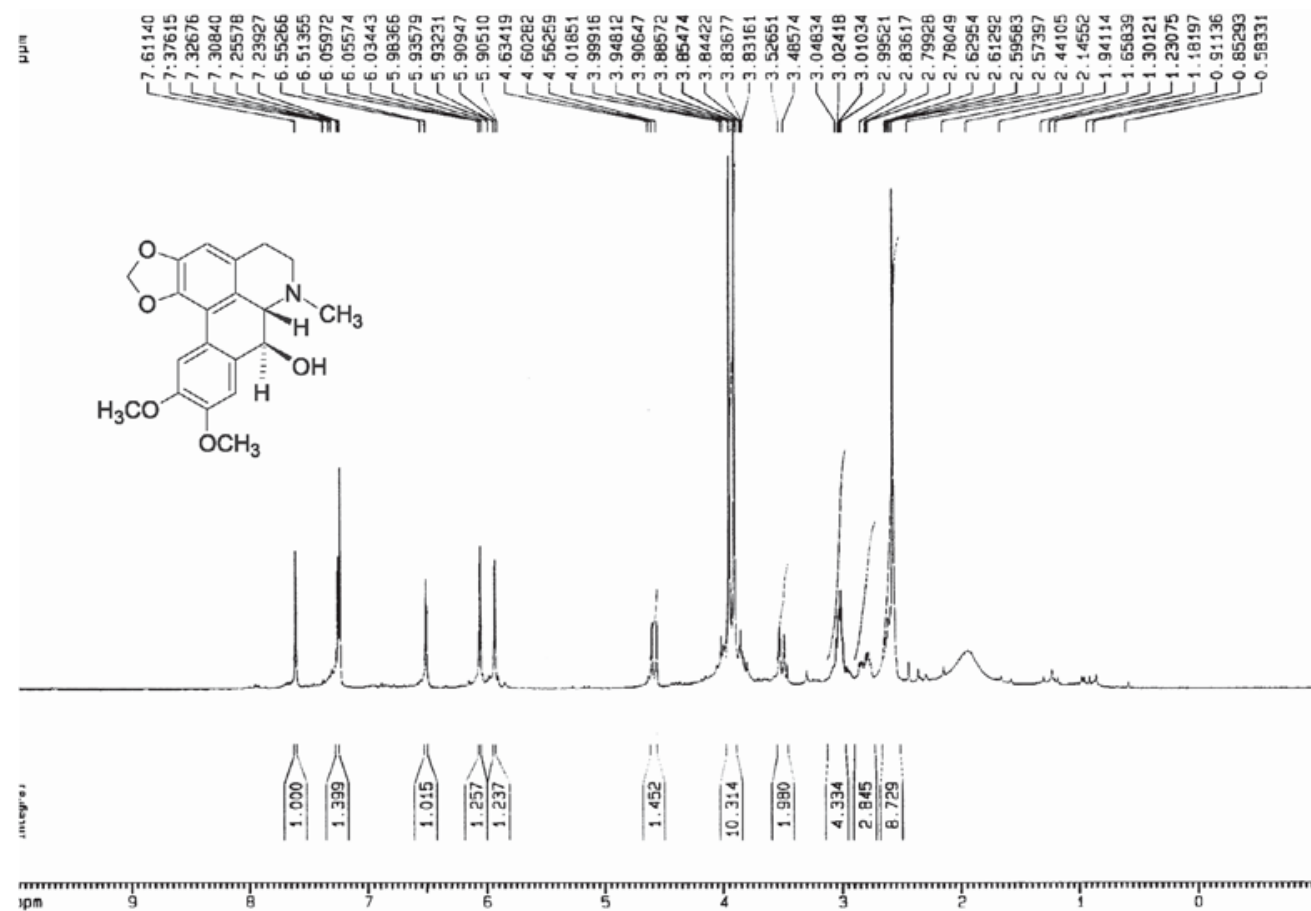

Figure S6. ${ }^{1} \mathrm{H}$ NMR spectrum of compound $2\left(300 \mathrm{MHz}, \mathrm{CDCl}_{3}\right)$.

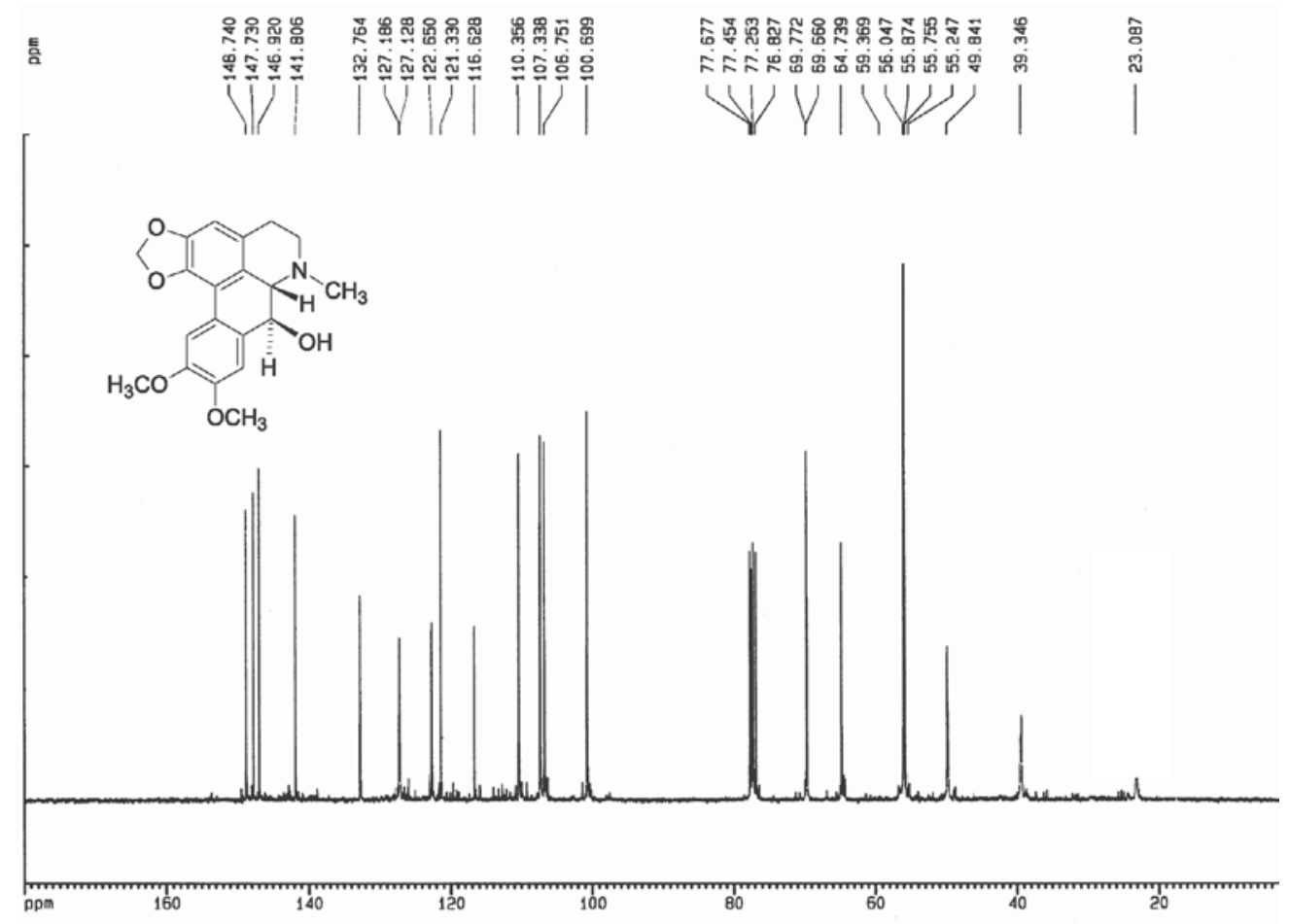

Figure S7. ${ }^{13} \mathrm{C}$ NMR spectrum of compound $2\left(75 \mathrm{MHz}, \mathrm{CDCl}_{3}\right)$. 

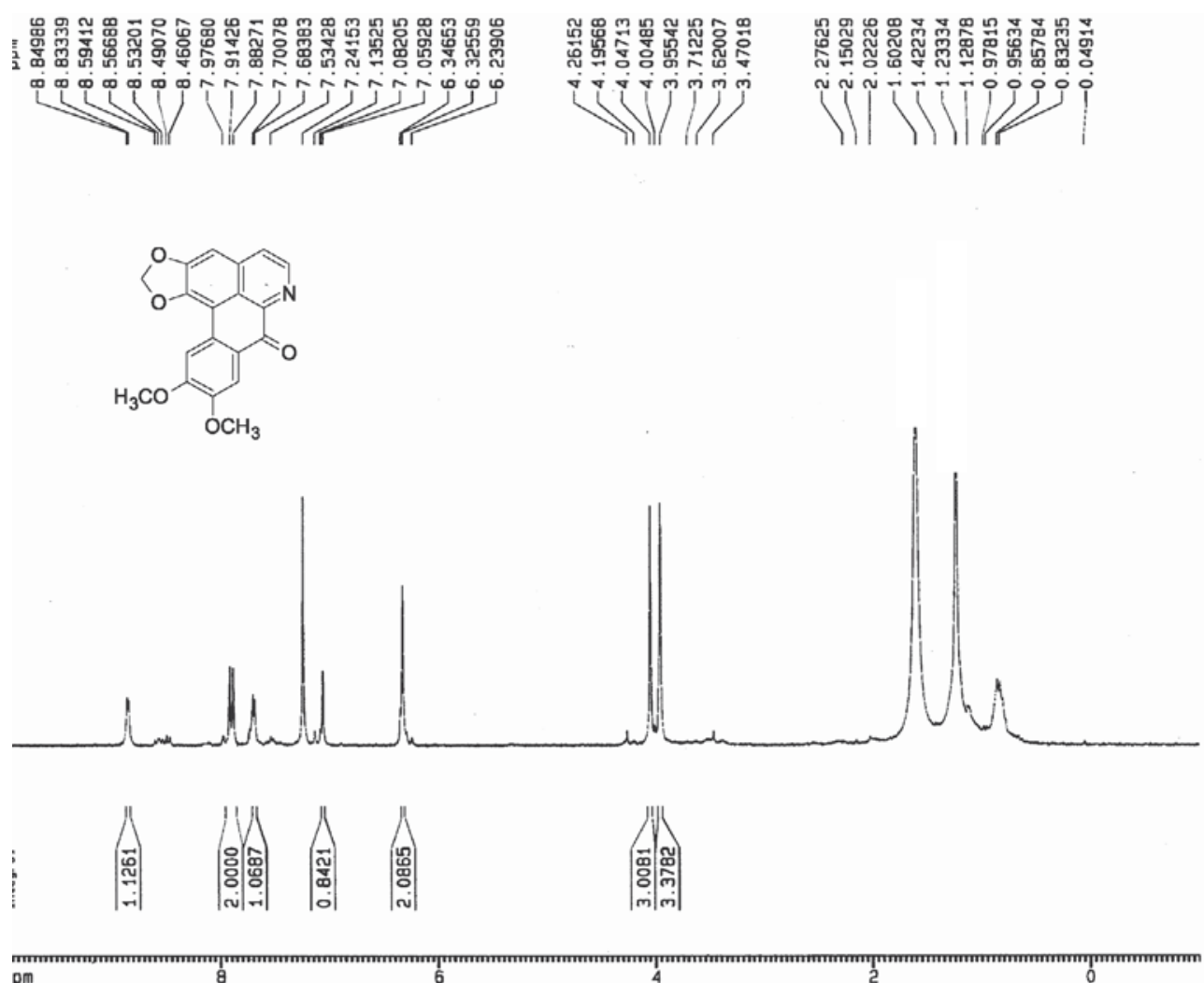

Figure S8. ${ }^{1} \mathrm{H}$ NMR spectrum of compound 3 (300 $\left.\mathrm{MHz}, \mathrm{CDCl}_{3}\right)$.

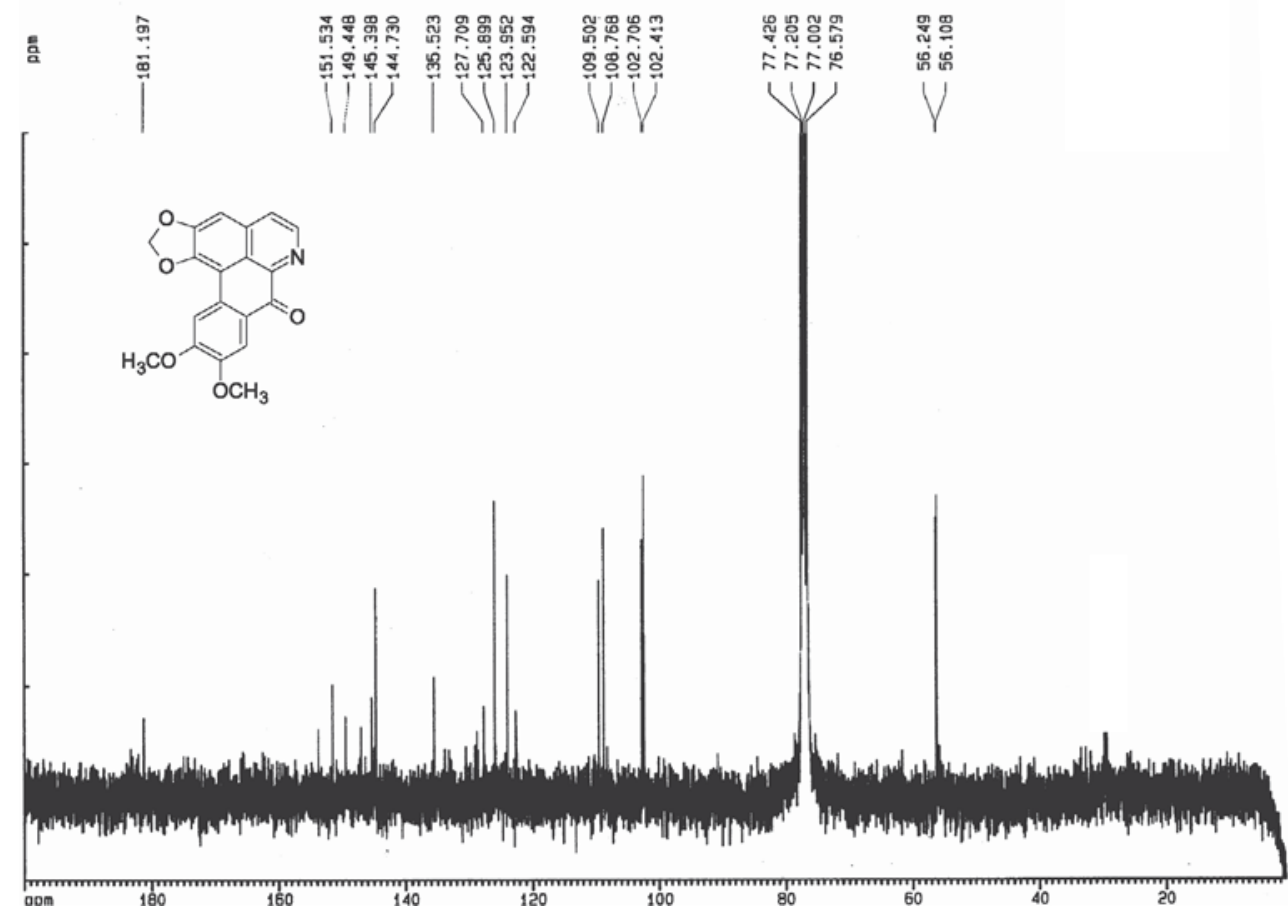

Figure S9. ${ }^{13} \mathrm{C}$ NMR spectrum of compound $3\left(75 \mathrm{MHz}, \mathrm{CDCl}_{3}\right)$. 
SG

Chemical Constituents of the Underground Stem Bark of Duguetia furfuracea (Annonaceae)

J. Braz. Chem. Soc.

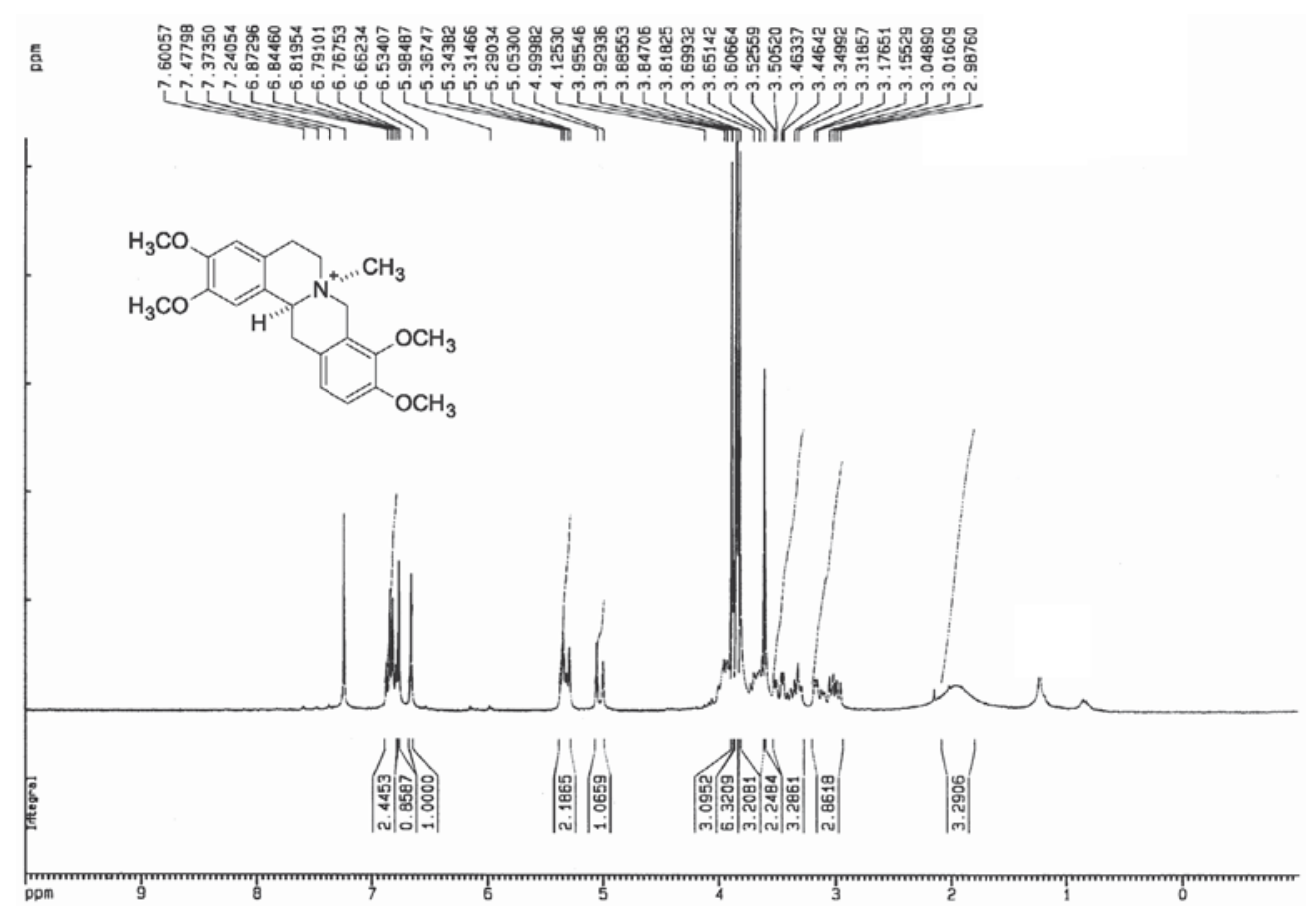

Figure S10. ${ }^{1} \mathrm{H}$ NMR spectrum of compound $4\left(300 \mathrm{MHz}, \mathrm{CDCl}_{3}\right)$.

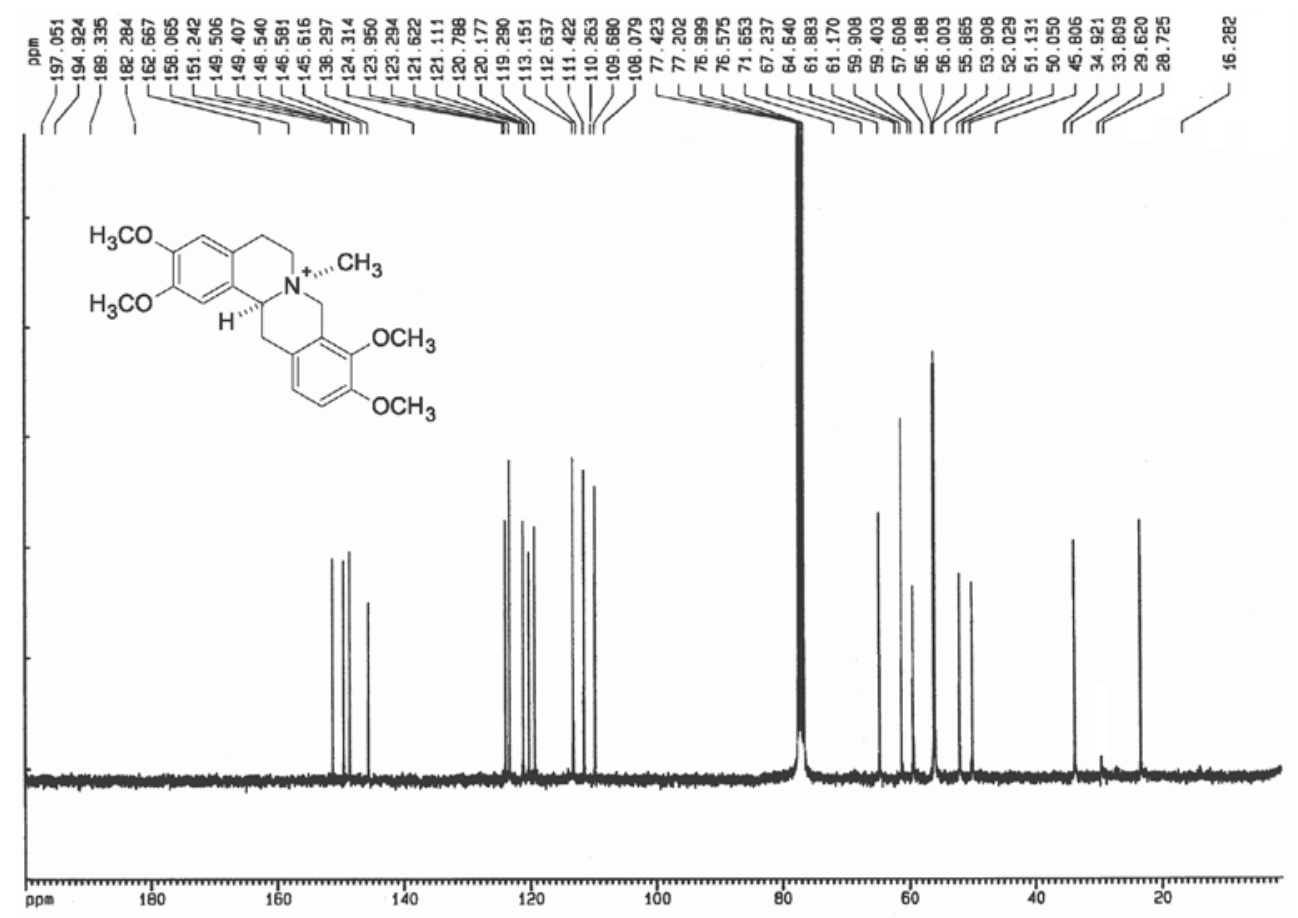

Figure S11. ${ }^{13} \mathrm{C}$ NMR spectrum of compound $4\left(75 \mathrm{MHz}, \mathrm{CDCl}_{3}\right)$. 


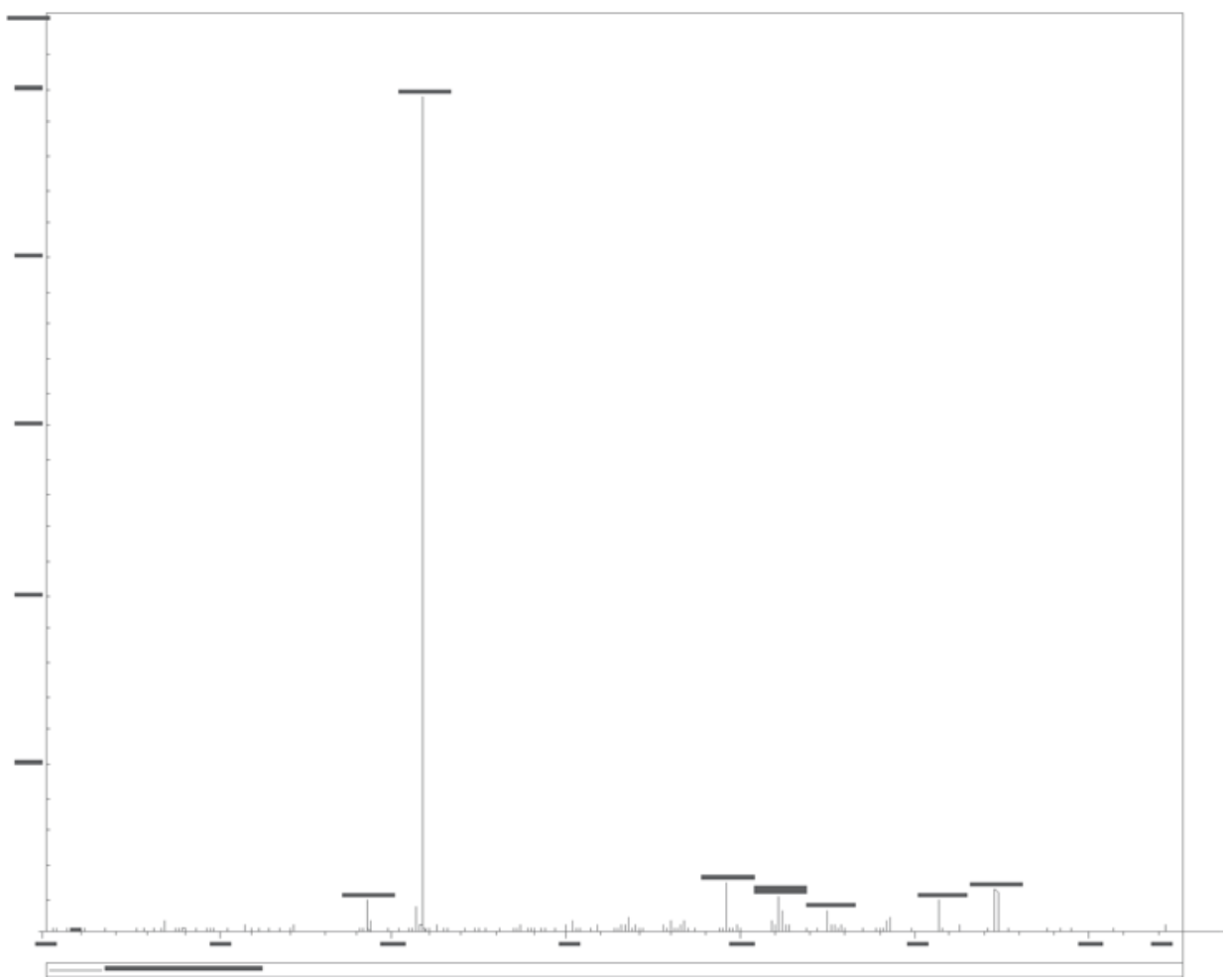

Figure S12. HR-ESIMS/MS spectrum of compound 4 (positive mode).

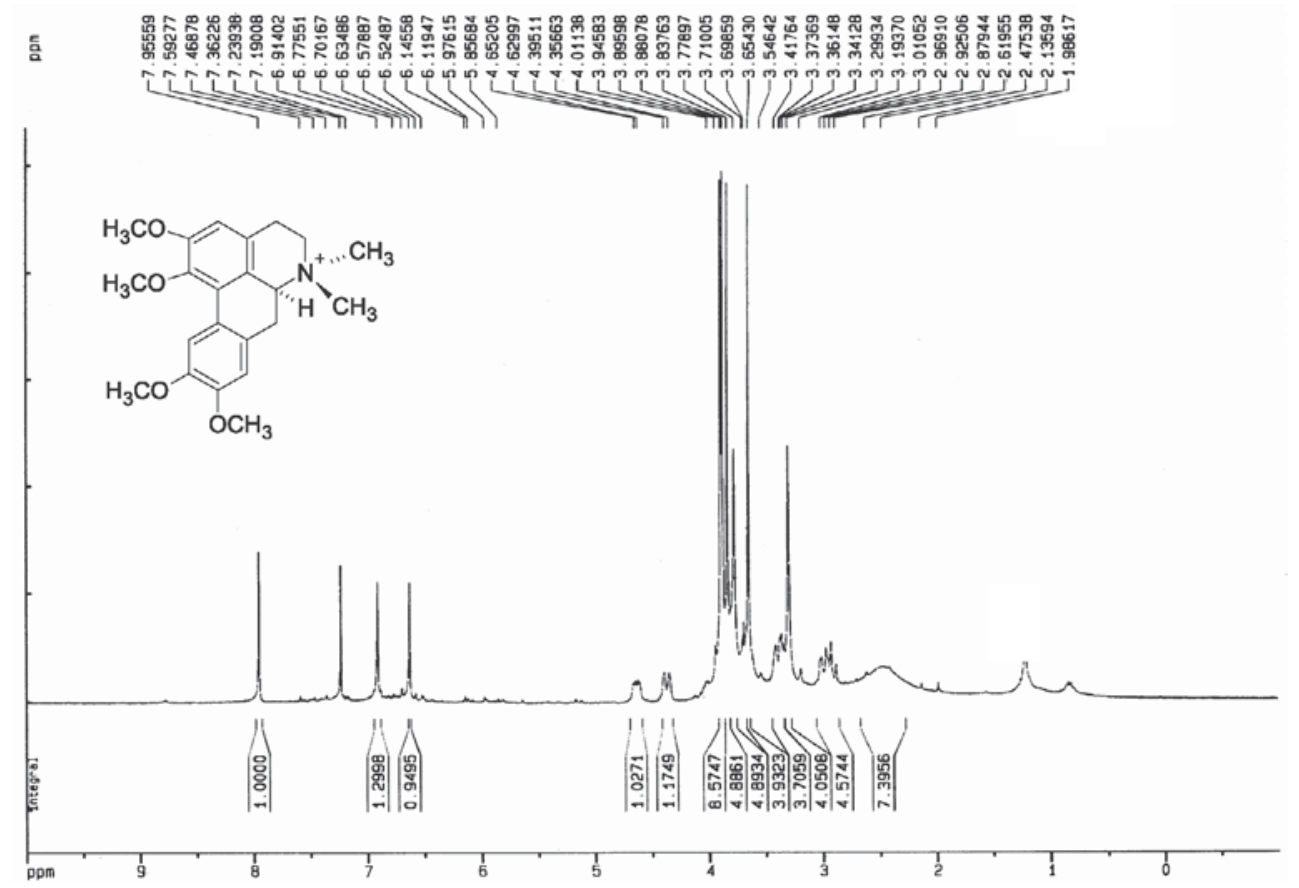

Figure S13. ${ }^{1} \mathrm{H} \mathrm{NMR}$ spectrum of compound $5\left(300 \mathrm{MHz}, \mathrm{CDCl}_{3}\right)$. 


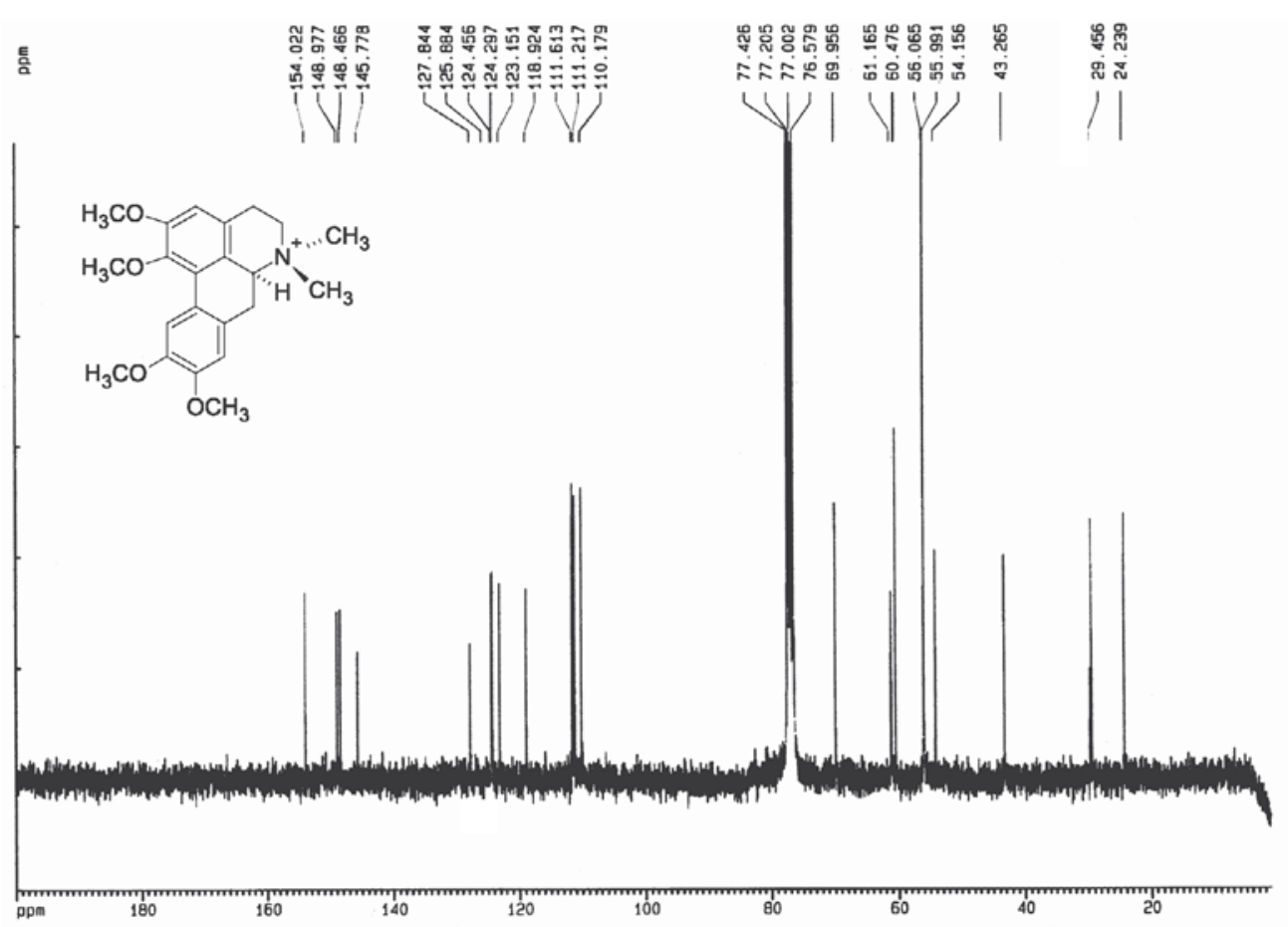

Figure S14. ${ }^{13} \mathrm{C}$ NMR spectrum of compound $5\left(75 \mathrm{MHz}, \mathrm{CDCl}_{3}\right)$.

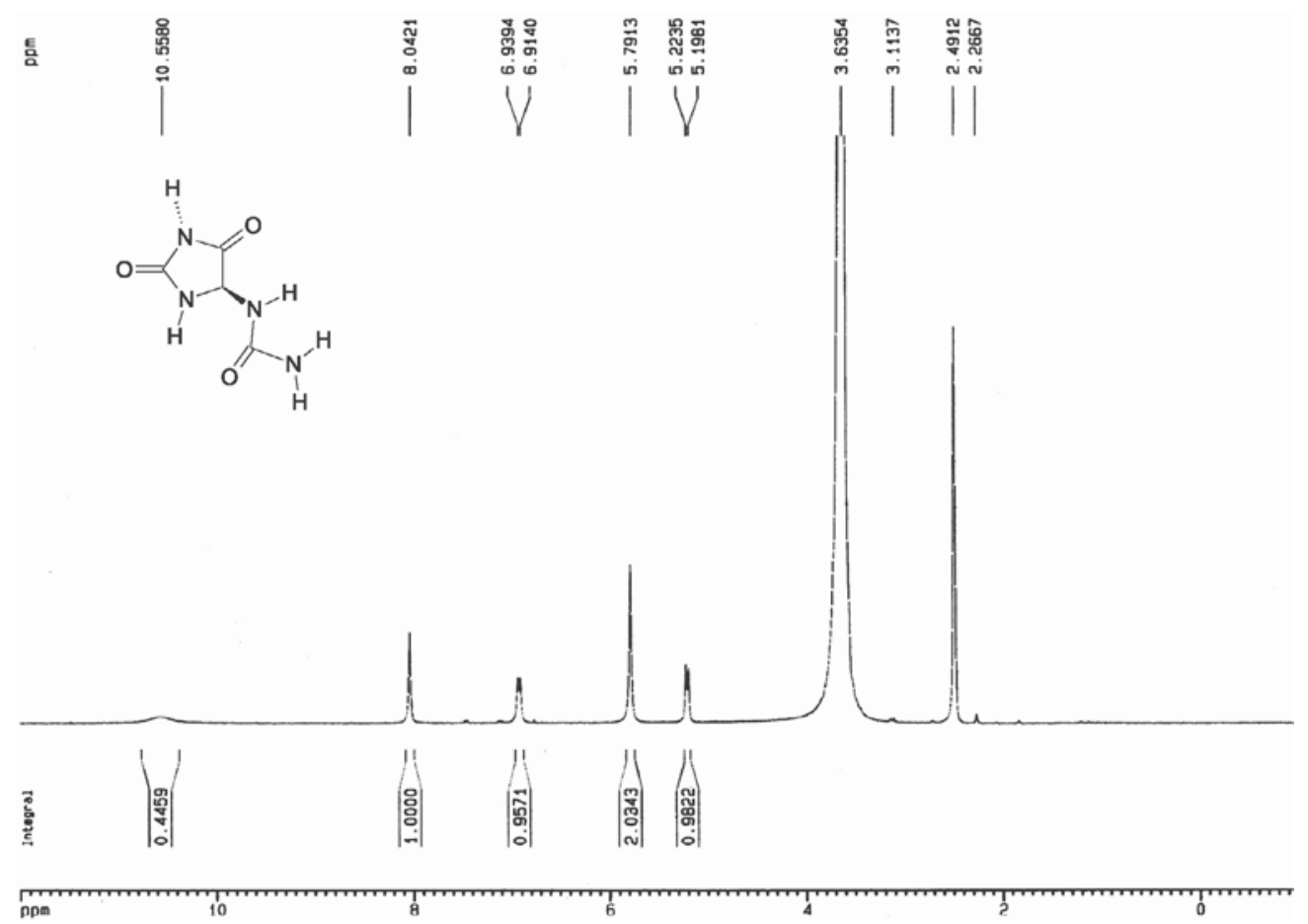

Figure S15. ${ }^{1} \mathrm{H}$ NMR spectrum of compound 6 (300 MHz, DMSO-d $)$. 


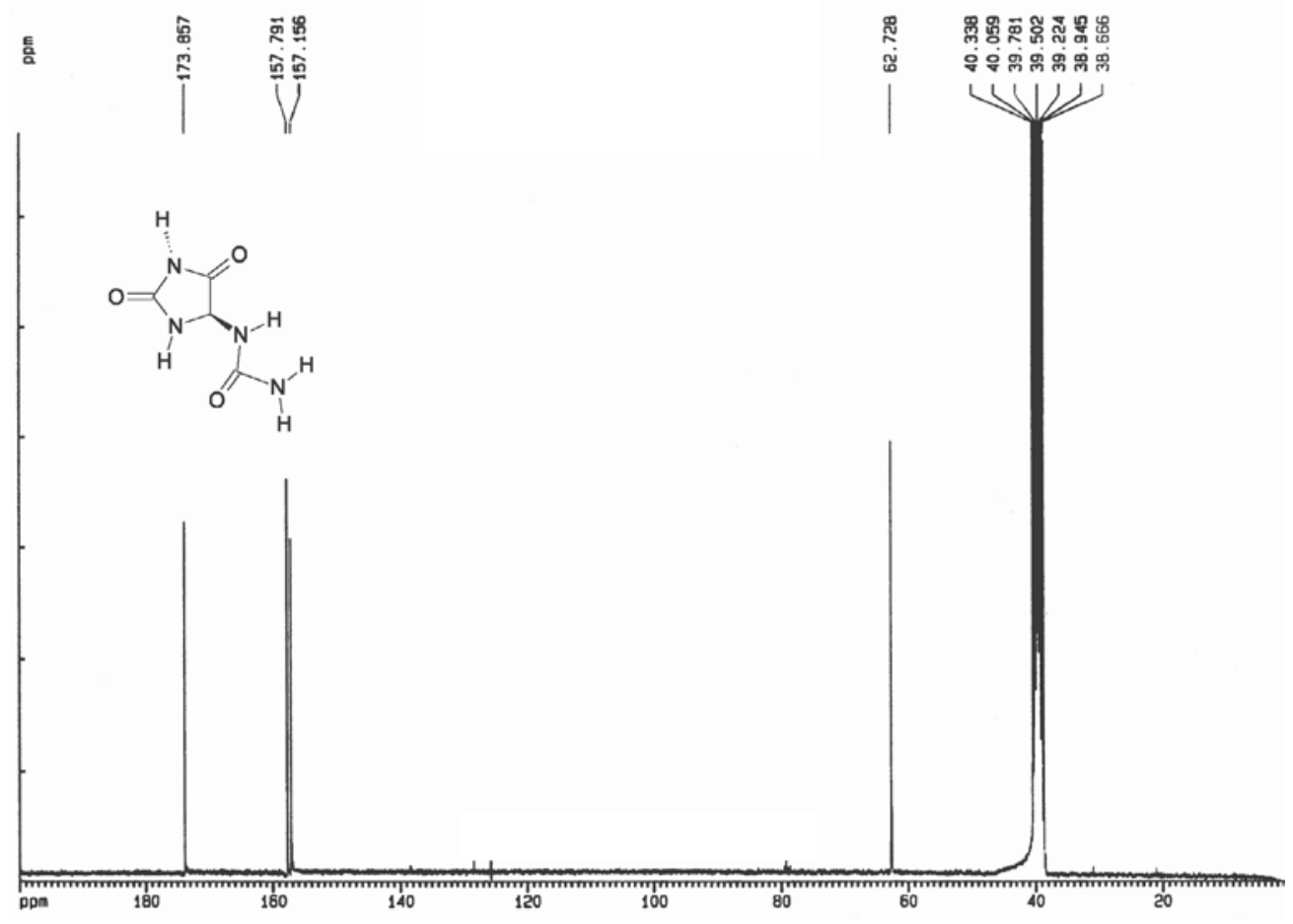

Figure S16. ${ }^{13} \mathrm{C}$ NMR spectrum of compound 6 (75 MHz, DMSO-d ${ }_{6}$ ).

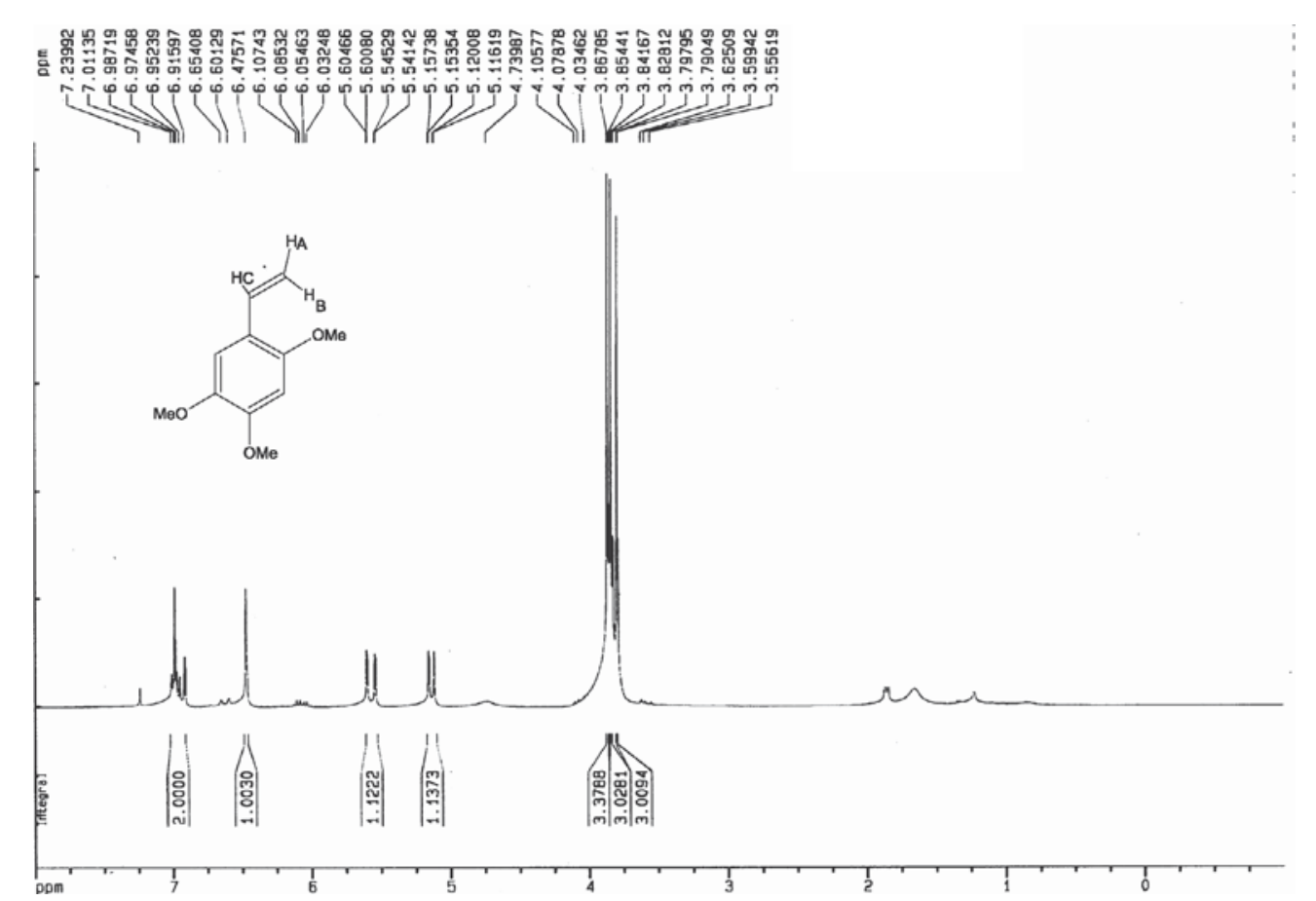

Figure S17. ${ }^{1} \mathrm{H}$ NMR spectrum of compound $7\left(300 \mathrm{MHz}, \mathrm{CDCl}_{3}\right)$. 


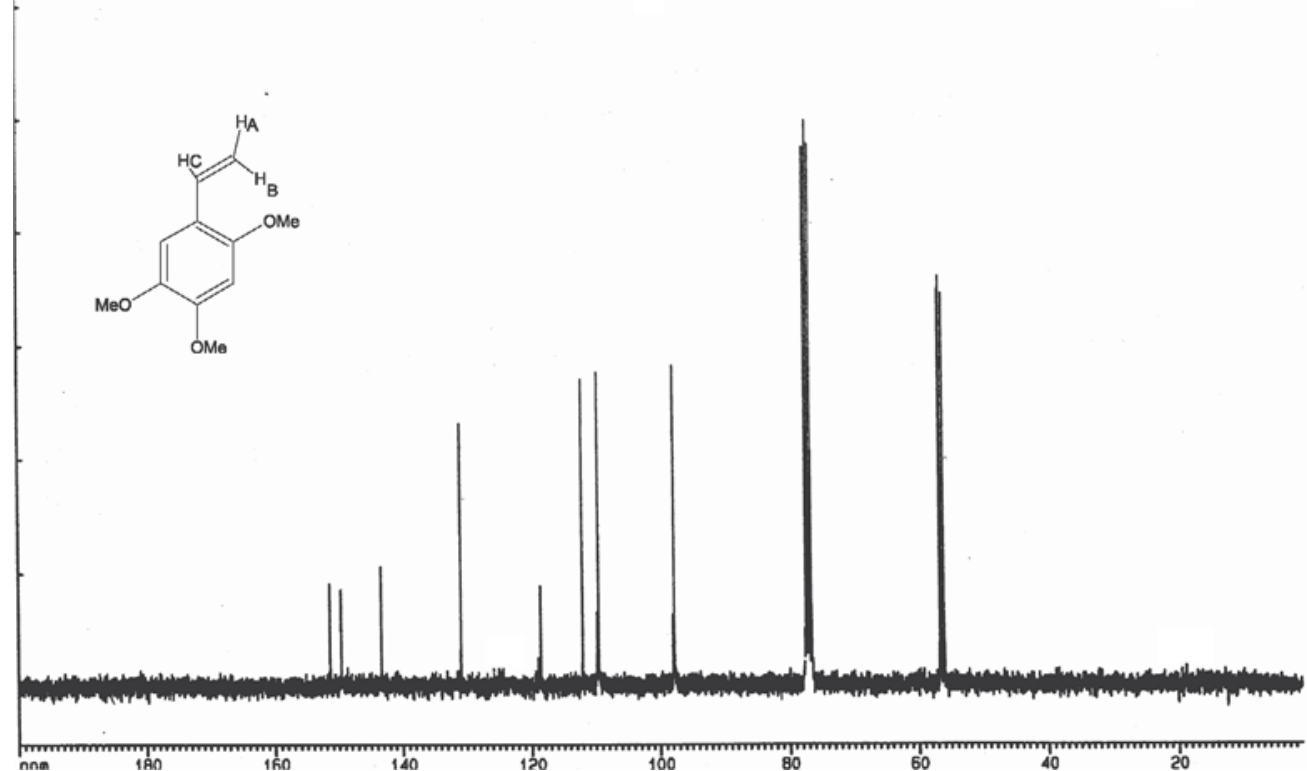

Figure S18. ${ }^{13} \mathrm{C}$ NMR spectrum of compound $7\left(75 \mathrm{MHz}, \mathrm{CDCl}_{3}\right)$.

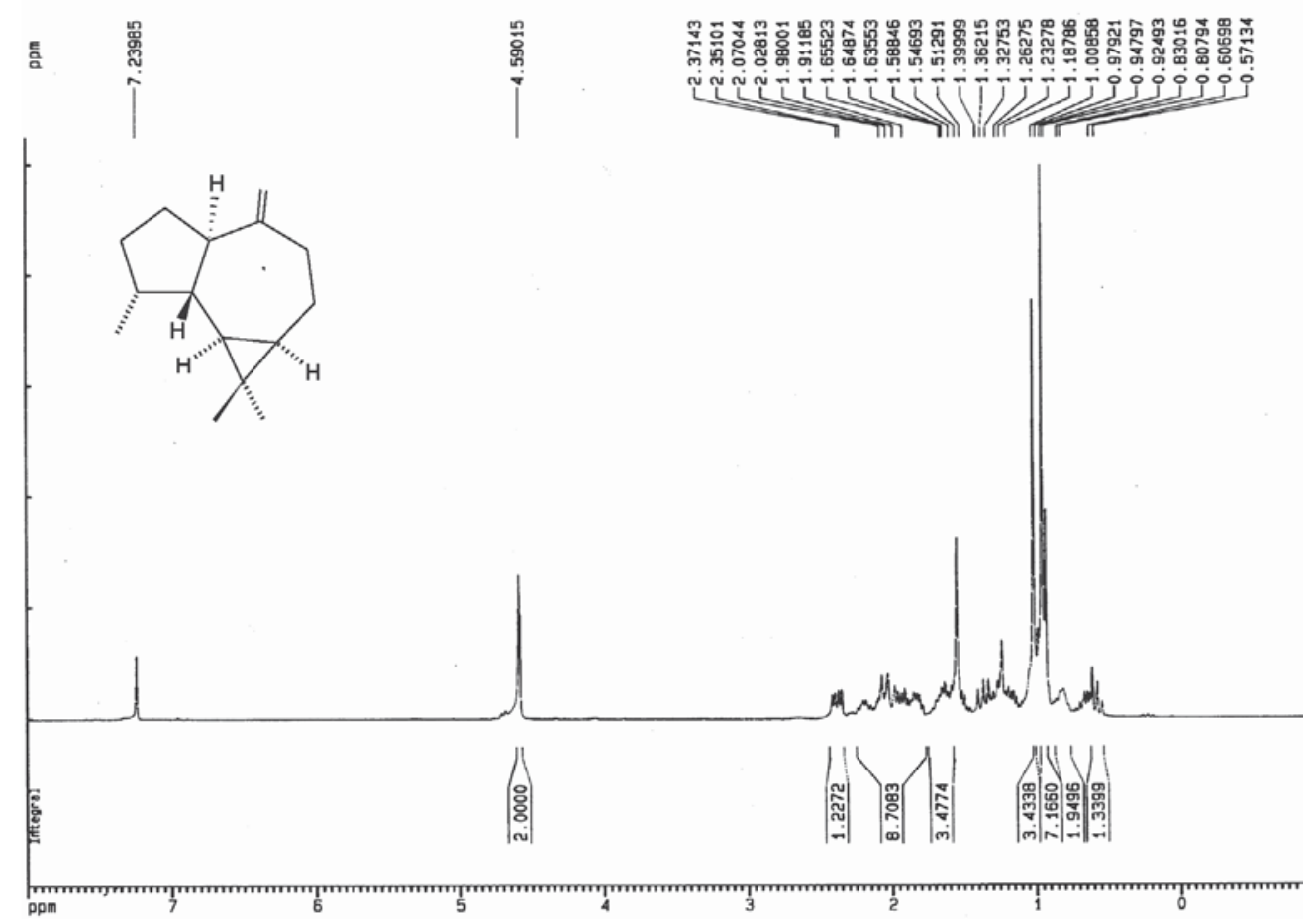

Figure S19. ${ }^{1} \mathrm{H}$ NMR spectrum of compound $9\left(300 \mathrm{MHz}, \mathrm{CDCl}_{3}\right)$. 
豆

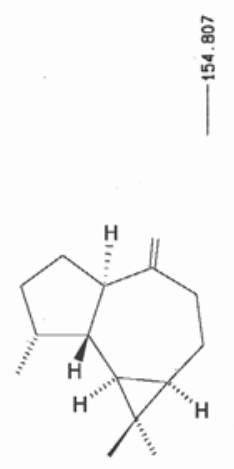

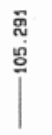

กิ ํㅗำ

RREL

$\longrightarrow$ V Vill

Figure S20. ${ }^{13} \mathrm{C}$ NMR spectrum of compound $9\left(75 \mathrm{MHz}, \mathrm{CDCl}_{3}\right)$.

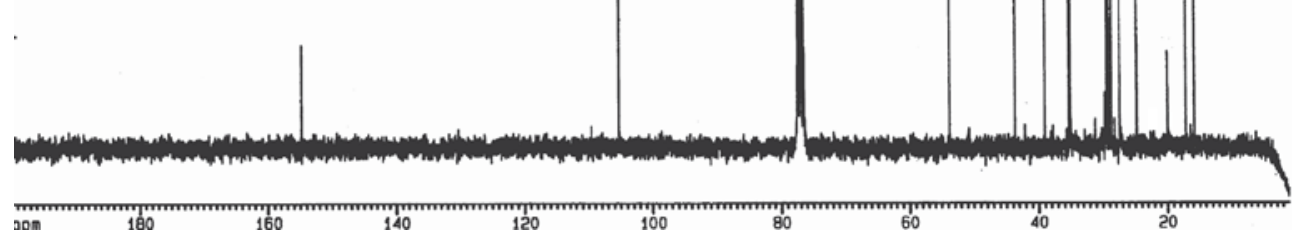

80

.

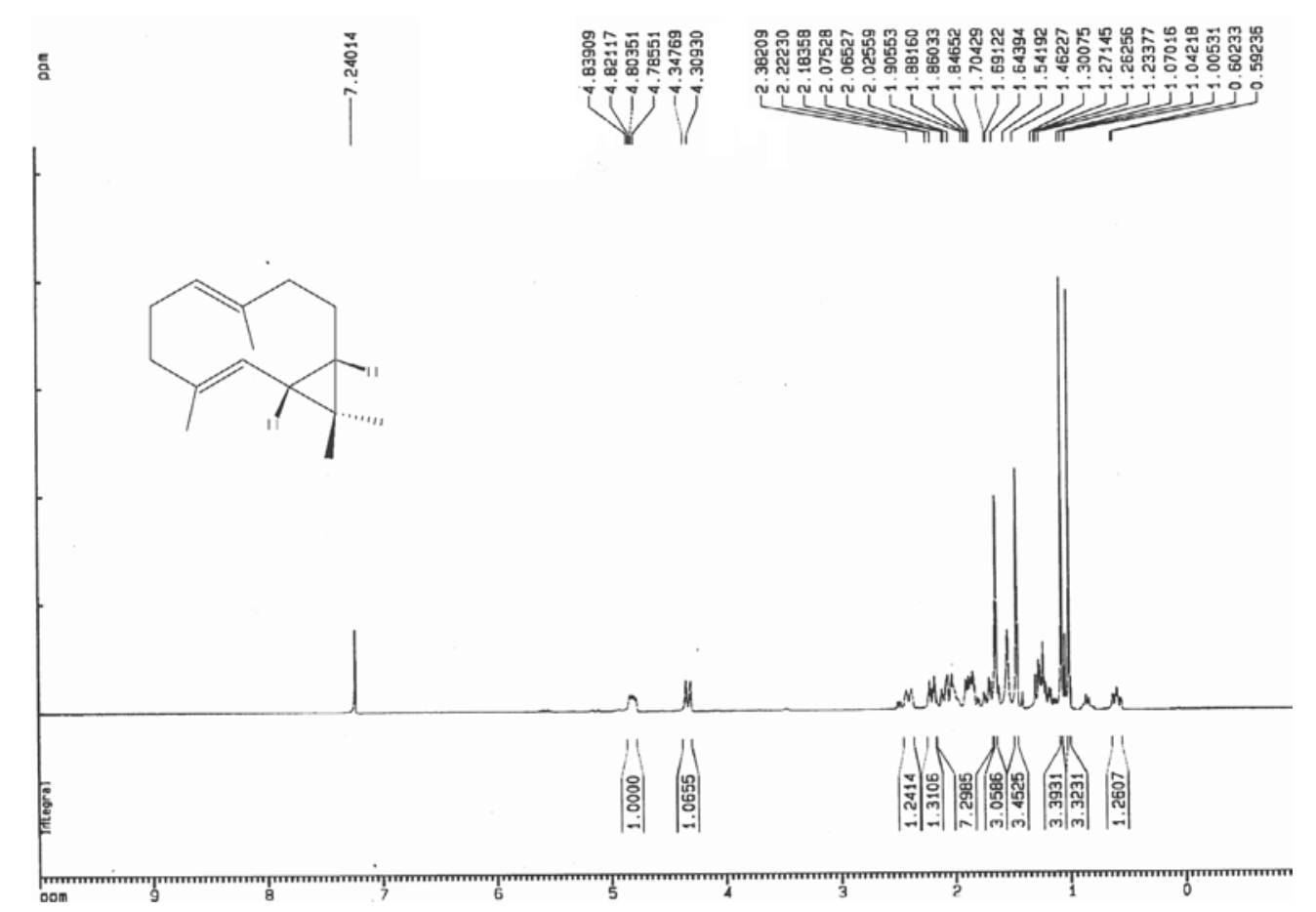

Figure S21. ${ }^{1} \mathrm{H}$ NMR spectrum of compound $10\left(300 \mathrm{MHz}, \mathrm{CDCl}_{3}\right)$. 


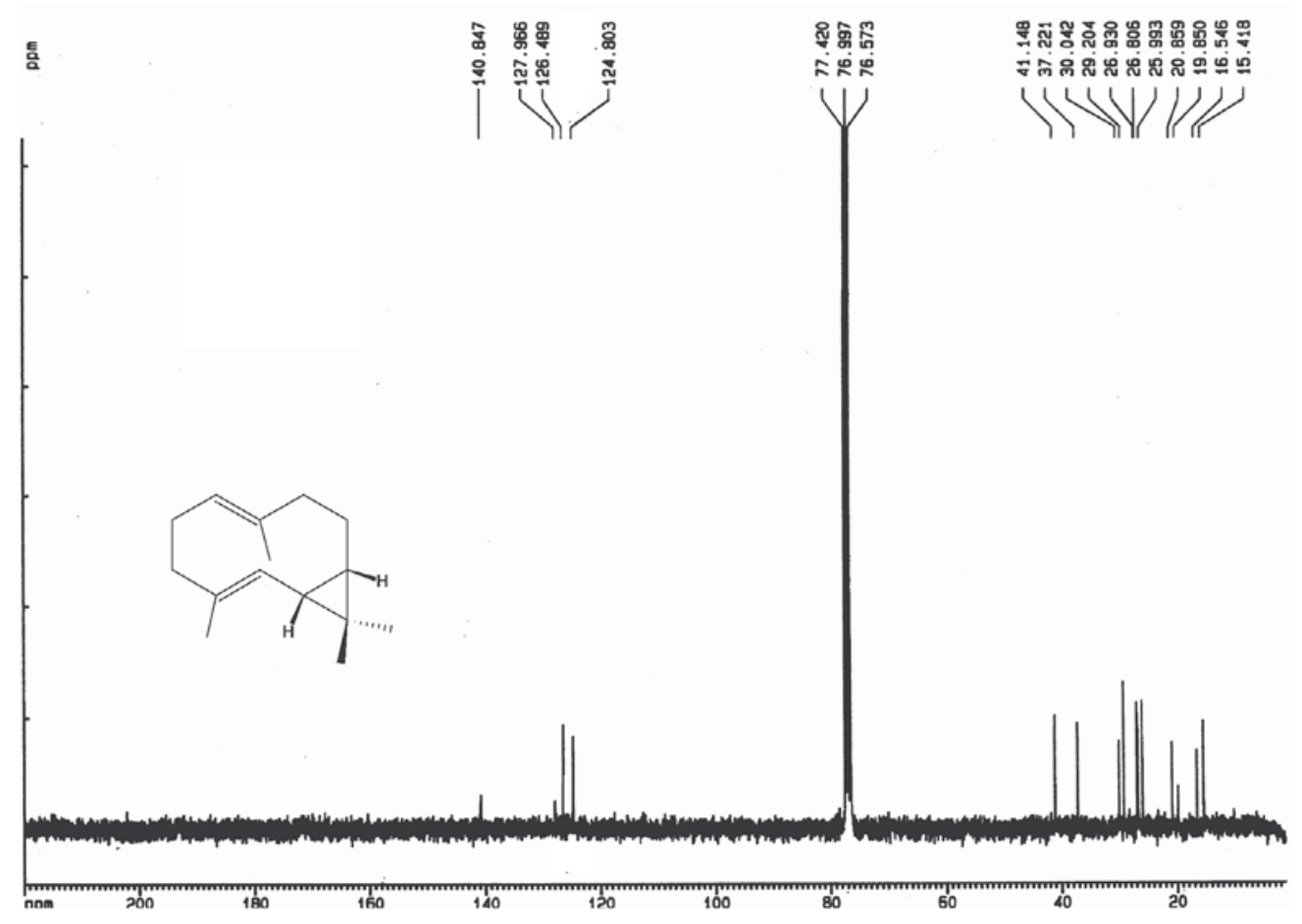

Figure S22. ${ }^{13} \mathrm{C}$ NMR spectrum of compound $\mathbf{1 0}\left(75 \mathrm{MHz}, \mathrm{CDCl}_{3}\right)$.

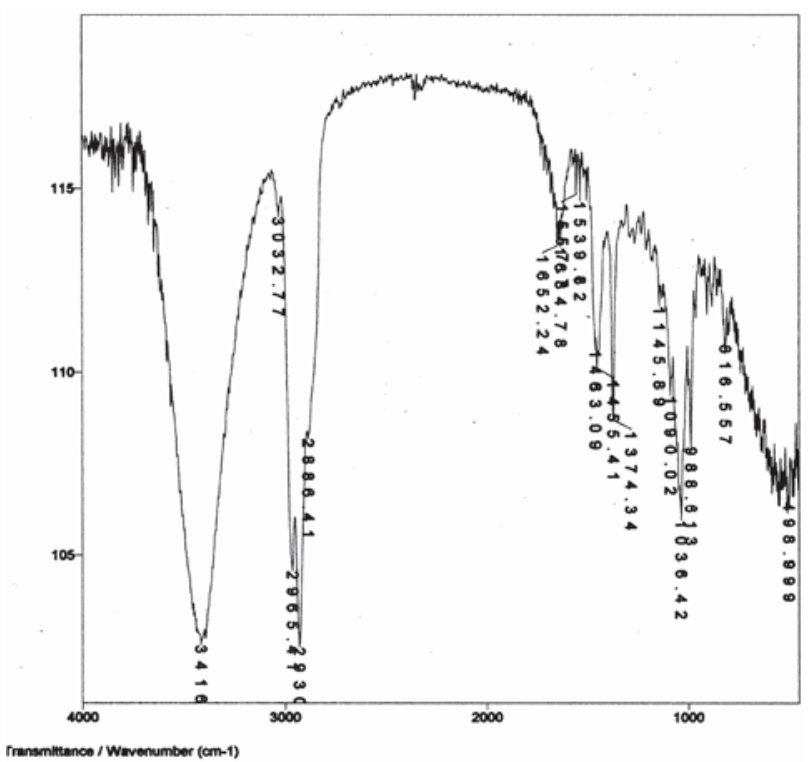

Figure S23. FTIR spectrum of compound 13. 

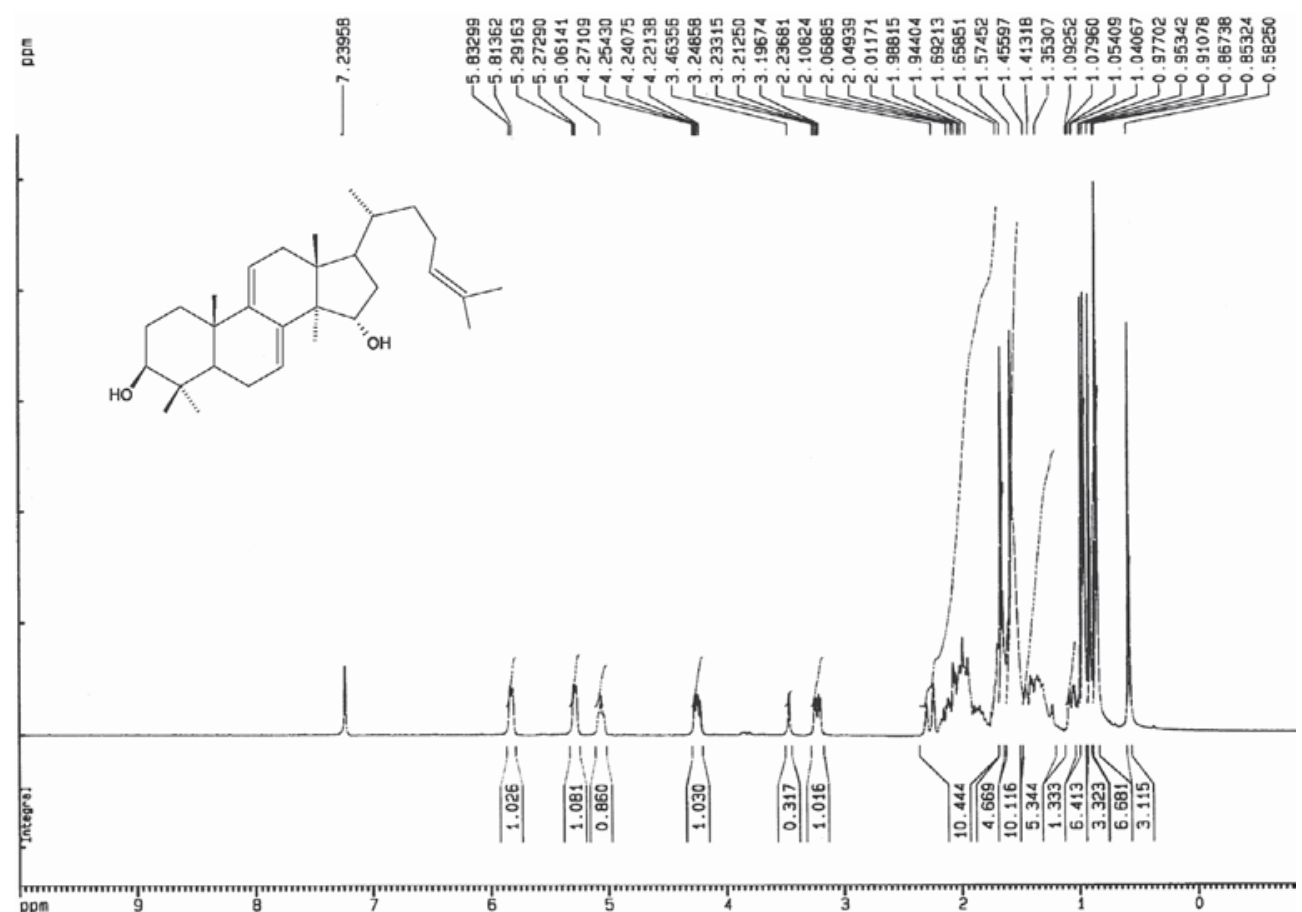

Figure S24. ' $\mathrm{H}$ NMR spectrum of compound $13\left(300 \mathrm{MHz}, \mathrm{CDCl}_{3}\right)$.

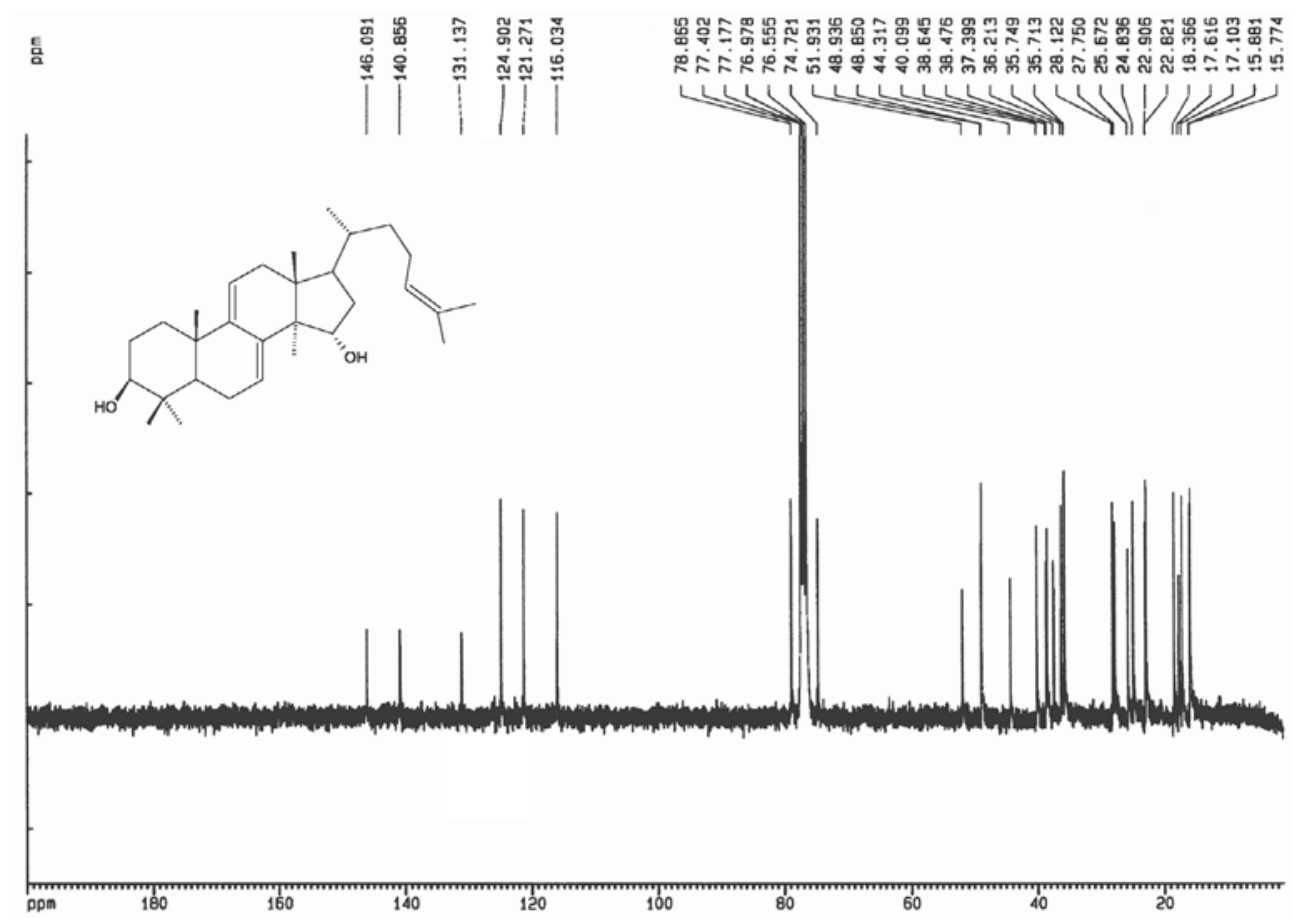

Figure S25. ${ }^{13} \mathrm{C}$ NMR spectrum of compound $13\left(75 \mathrm{MHz}, \mathrm{CDCl}_{3}\right)$. 


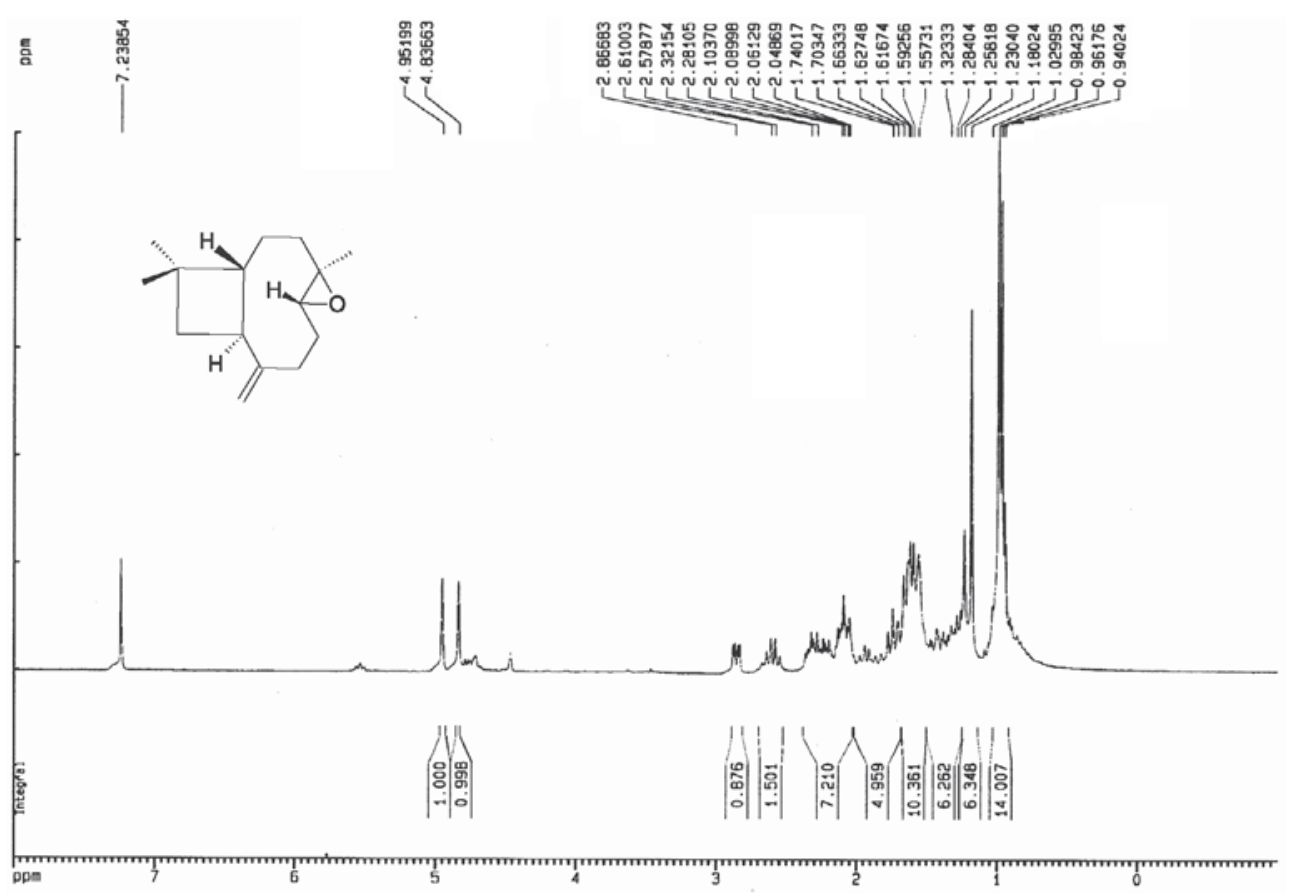

Figure S26. ${ }^{1} \mathrm{H}$ NMR spectrum of compound $14\left(300 \mathrm{MHz}, \mathrm{CDCl}_{3}\right)$.

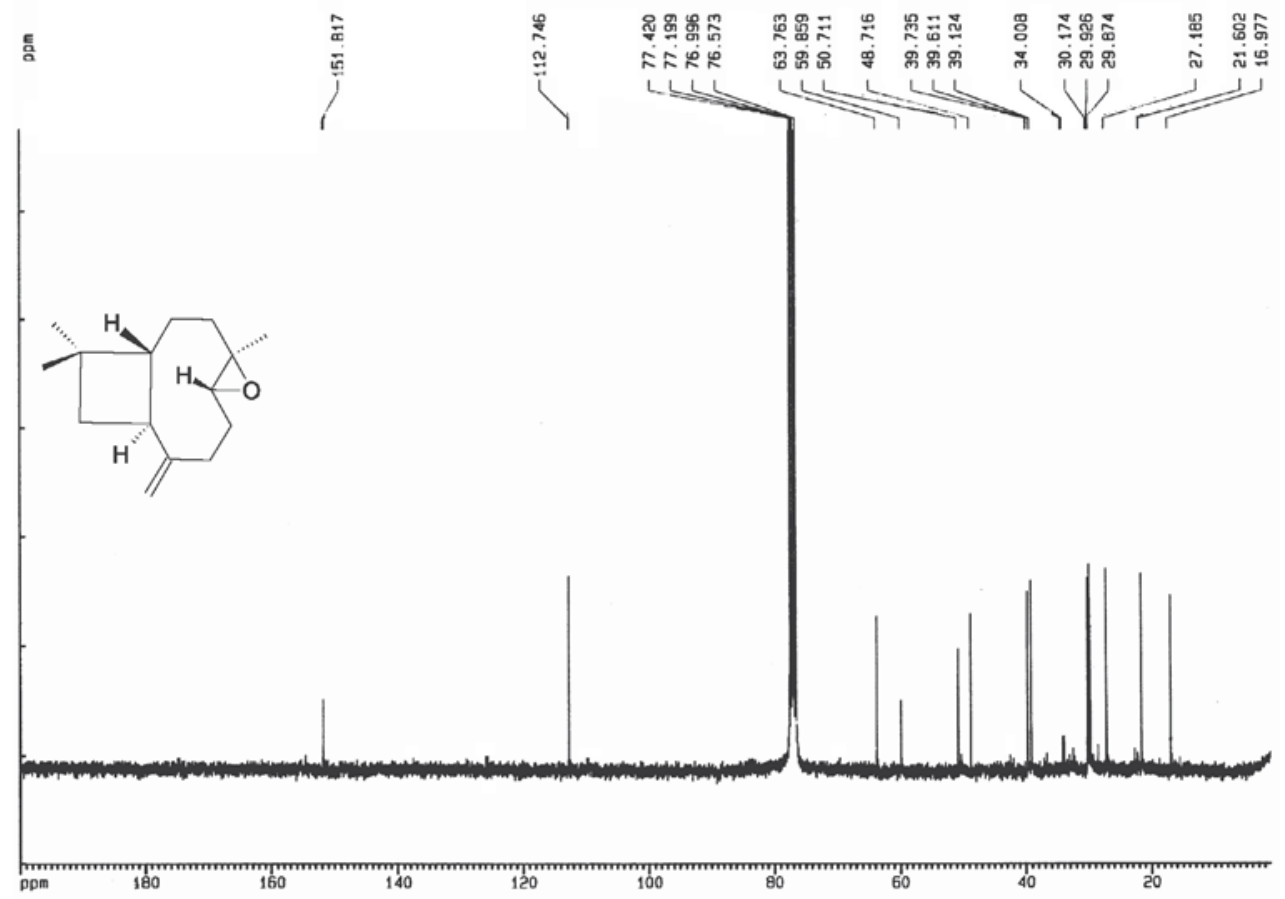

Figure S27. ${ }^{13} \mathrm{C}$ NMR spectrum of compound $14\left(75 \mathrm{MHz}, \mathrm{CDCl}_{3}\right)$. 


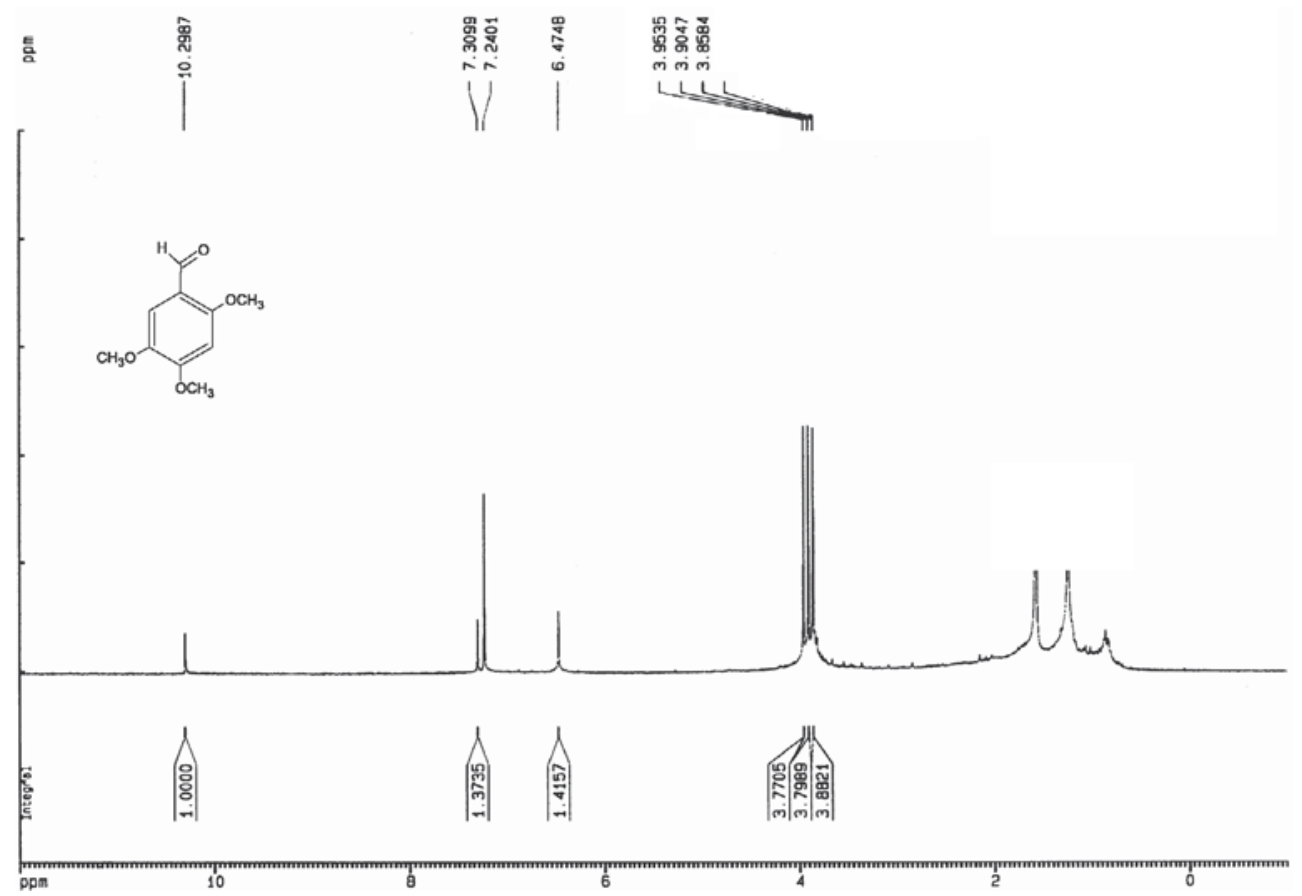

Figure S28. ${ }^{1} \mathrm{H} \mathrm{NMR}$ spectrum of compound $15\left(300 \mathrm{MHz}, \mathrm{CDCl}_{3}\right)$.

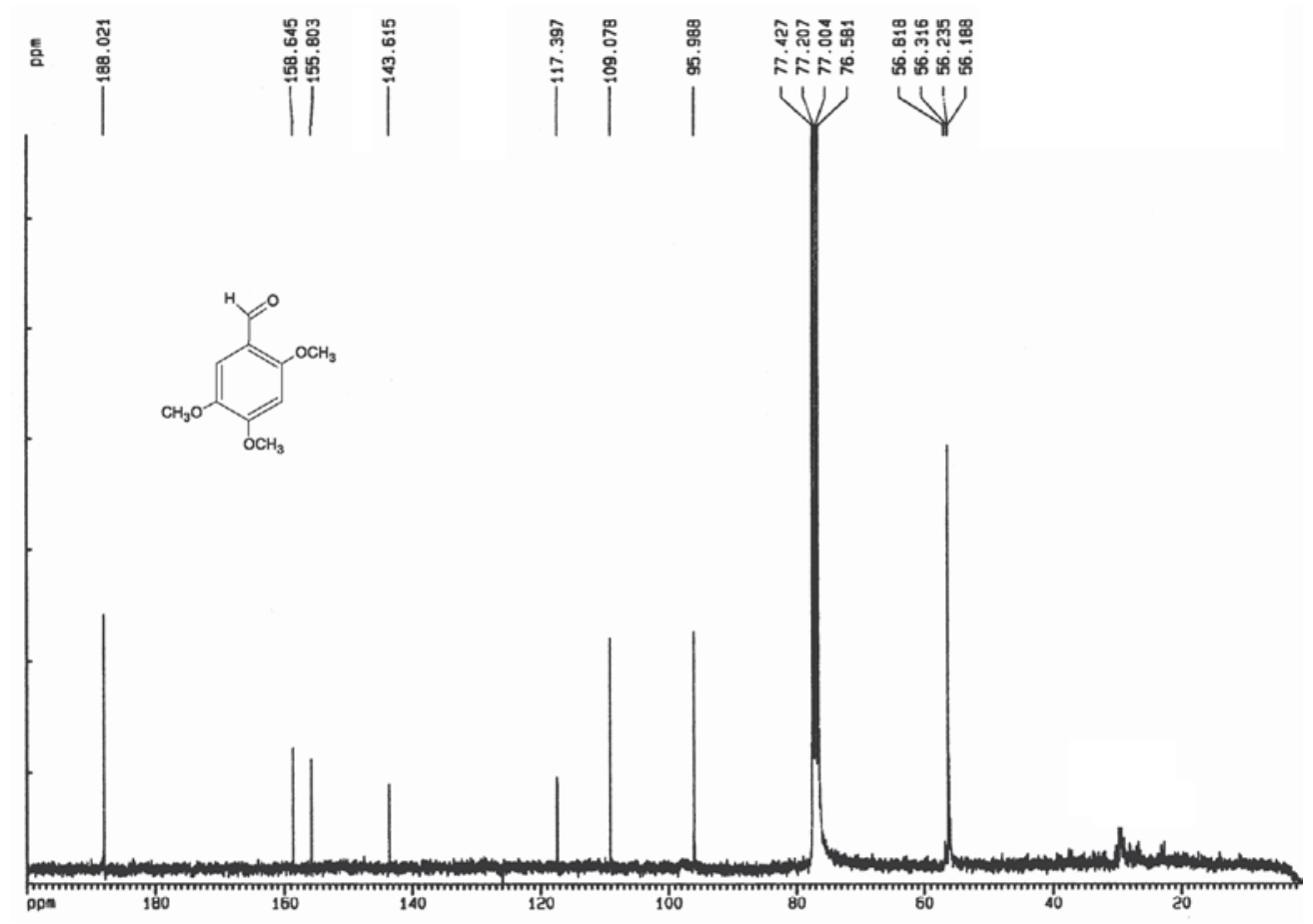

Figure S29. ${ }^{13} \mathrm{C}$ NMR spectrum of compound $15\left(75 \mathrm{MHz}, \mathrm{CDCl}_{3}\right)$. 